\title{
Granitoid emplacement during a thrusting event: structural analysis, microstructure and quartz $c$-axis patterns. An example from Hercynian plutons in the French Massif Central
}

\author{
Manuel Duguet and Michel Faure
}

Institut des Sciences de la Terre d'Orléans, U.M.R. C.N.R.S 6113, Université d'Orléans, BP 6759, F-45067, Orléans cedex 2, France

\section{Abstract}

In the French Massif Central, the Rouergue-Albigeois area consists of three tectonic units stacked during the Hercynian orogeny. The structural analysis of the units and particularly the quartz $(c)$ axis, textural and structural observations in the syntectonic Pinet-type plutons allow us to determine the deformation history. A first thrusting event, D1, is responsible for a southwestward emplacement of the high-grade Lévézou nappe, above the Lower Gneiss Unit itself overlying the para-autochthonous micaschists. In Late Devonian-Early Carboniferous, this stack of nappes experienced a second event, D2, characterized by a top-to-the-NW emplacement under medium pressure/medium temperature conditions of the paraautochtonous unit upon the Lower Gneiss Unit. During D2, the Pinet-type plutons were deformed by a shearing consistent with the kinematics recorded in the country rocks. In contrast to previous works, which considered the Pinet-type plutons emplacement to be coeval with the D2 event, we argue that the emplacement of the plutons occurred during the top-tothe-SW D1 nappe stacking. This work emphasizes the importance of the quartz $\langle c\rangle$ axis and microstructure analysis for the identification of the early structural history in polyphase deformed terranes.

Author Keywords: Author Keywords: Quartz 〈c $\rangle$ axis fabrics; Granite emplacement; Nappe tectonics; Hercynian belt; Polyphase deformation

\section{Introduction}

During the two last decades, numerous studies have underlined the interest of granitoids as crustal scale deformation markers (e.g. Gapais, 1989 and Pons et al., 1992). Due to the abundance of granite magmatism, the Hercynian orogeny of Europe is well suited to tackle this question. In the French Hercynian Belt, pluton emplacement in transcurrent or extensional regimes are commonly described ( Berthé et al., 1979; Faure, 1995 and Roig et al., 1996); however, the structure of granitic plutons emplaced during the early collision stage (i.e. in a thrusting setting) is poorly documented. Two main reasons may account for this lack of studies undertaken on granitoid emplacement in compressional setting in the Hercynian Belt. Firstly, most of the granitoids were emplaced during the last stages of the orogeny (ca. 320-300 Ma; e.g. Pin and Peucat, 1986) when extensional or transcurrent tectonics 
predominated. Secondly, in such early syn-compressional plutons, polyphase deformation is common and thus the late events commonly erased the early compressional structures.

This paper deals with a structural and kinematic study of granitoids emplaced in a compressional setting. From the example of gneissic granites and their host rocks cropping out in the Rouergue area of the South French Massif Central (Fig. 1), we argue that the Hercynian plutons experienced a polyphase deformation. More precisely, the early deformation phase is coeval with the emplacement of the plutons and top-to-the-SW nappe stacking. The second phase developed under post-solidus conditions during a top-to-the-NW backthrusting. The textural relationships, the development of quartz microfabrics and $\langle c\rangle$ axis patterns are used to assess the kinematics inferred from the regional field study.

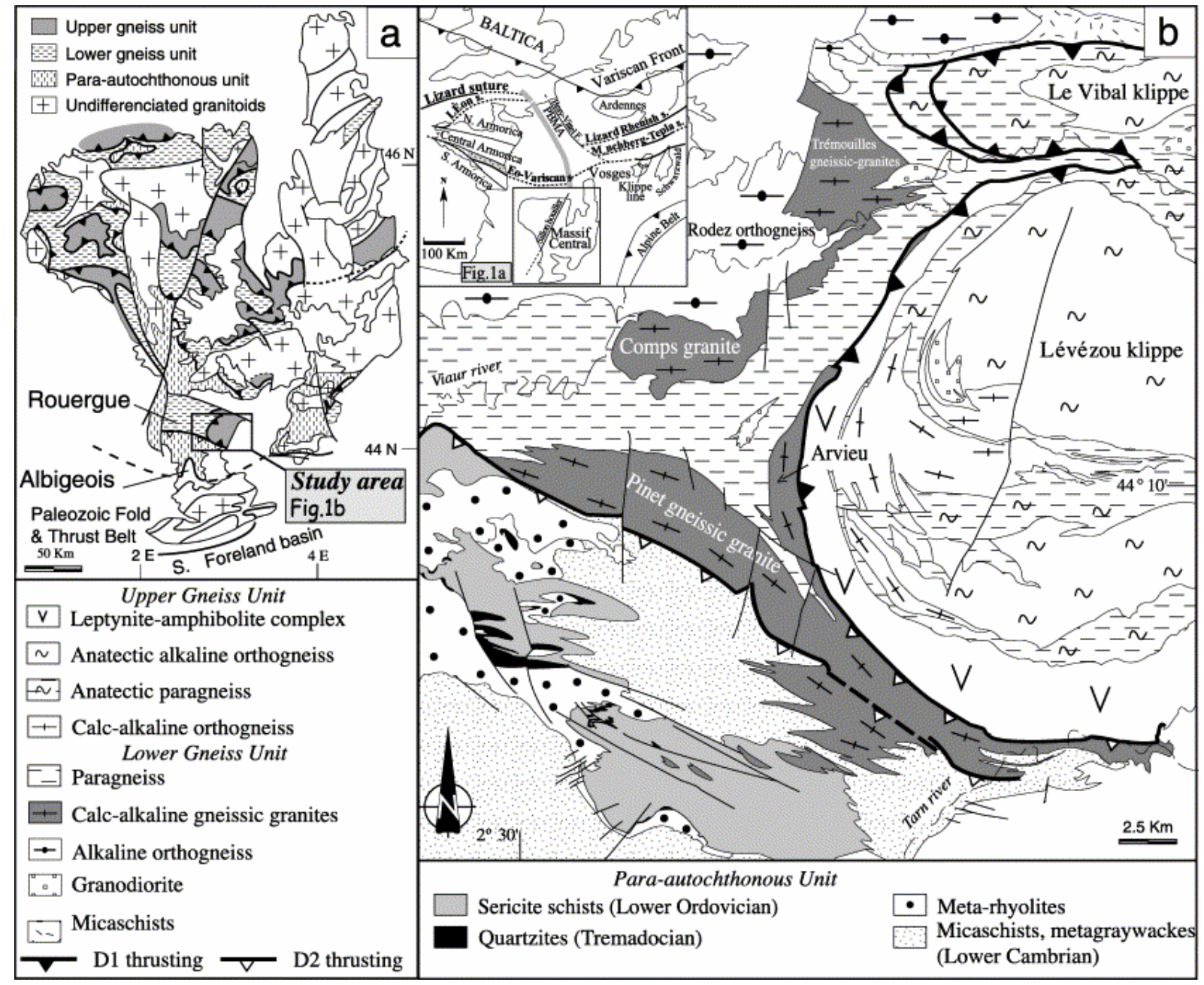

Fig. 1. (a) Structural map of the French Massif Central with location of (b). (b) Geological map of the Eastern Rouergue area (modified from Guérangé-Lozes and Burg, 1990). 


\section{Geological setting}

\subsection{The lithotectonic units}

The French Massif Central is a part of the Hercynian belt, which formed during the collision between Gondwana, Armorica and Laurussia from south to north, respectively. According to previous studies (e.g. Mattauer, 1974 and Matte, 1986), nappe emplacement was accommodated by a southward-directed thrusting. The stack of nappes recognized in the whole Massif Central is also observed in Eastern Rouergue ( Fig. 1a and b) ( Burg et al., 1986 and Ledru et al., 1989). In the study area, three units are described from top to bottom ( Fig. $\underline{1 b})$.

(i) The uppermost unit forms the Lévézou and Le Vibal klippes corresponding to the Upper Gneiss Unit (UGU). This nappe consists of a leptynite-amphibolite complex with eclogite boudins retrogressed to the amphibolite facies and migmatites that occupy the upper part of the unit. The eclogitization is dated Late Silurian $415 \pm 5 \mathrm{Ma}$ by $\mathrm{U} / \mathrm{Pb}$ on zircon and $407 \pm 7 \mathrm{Ma}$ by $\mathrm{Sm} / \mathrm{Nd}$ methods (Pin and Lancelot, 1982 and Paquette et al., 1995). The high pressure rocks are related to continental subduction of the North Gondwana margin below Armorica (e.g. Matte, 1986). Migmatization and retrogression of eclogites occurred during exhumation processes at the end of the collisional stage. In the French Massif Central, migmatites are dated Early Devonian (ca. 390-380 Ma; Duthou (1977) by Rb-Sr method on whole rock and Lafon (1986) by U/Pb method on zircon). Structural analysis and gravimetric study ( Bayer and Hirn, 1987) support the interpretation of the Lévézou area as a refolded klippen overturned to the northwest (Fig. 1).

(ii) The UGU is underlain by the Lower Gneiss Unit (LGU), in which no high-pressure relics have been described. This unit consists of metagreywackes and metapelites metamorphosed under middle pressure/middle temperature conditions and intruded by Early Paleozoic alkaline granites, which were transformed into augen-gneiss like the Rodez augen orthogneiss in the Rouergue area. The orthogneiss belongs to the pre-orogenic magmatic stage assumed to be of Cambrian-Ordovician age but which are not accurately dated. Several syntectonic porphyritic syenogranite plutons called the 'Pinet-type granitoids' (Burg and Teyssier, 1983) crop out in the LGU; since the study of their deformation is the topic of this paper, they will be presented in detail below.

(iii) The Para-autochthonous Unit (called locally the Saint-Sernin-sur-Rance nappe; Guérangé-Lozes and Alsac, 1986 and Guérangé-Lozes and Burg, 1990) is composed of acidic lavas dated $514 \mathrm{Ma}$ by $\mathrm{Rb}-\mathrm{Sr}$ on whole rock ( Delbos et al., 1964-1965) and greywackes. These rocks metamorphosed under greenschist to amphibolite facies conditions increasing from south to north ( Burg et al., 1986). Southward, outside of the study area, the Paraautochthonous Unit was thrust over Paleozoic sedimentary rocks forming a south verging fold-and-thrust belt ( $\underline{\text { Fig. 1a) }}$.

In the study area, the boundary between the LGU and the Para-autochthonous Unit is mapped as a vertical dextral strike-slip fault evolving to a flat-lying top-to-the-NW shear zone in the eastern and western parts, respectively (Fig. 1b; Burg et al., 1986). Due to its complex geometry, this tectonic surface is called the 'Pinet wrench-thrust'. The porphyritic Pinet-type syenogranites crop out as three massifs, namely the Pinet, Arvieu and Comps-Trémouilles plutons. The Pinet pluton (Fig. 1b) marks the contact between the LGU and the Paraautochthonous Unit; the Arvieu massif is located along the western flank of the Lévézou klippe whereas the Comps-Trémouilles pluton intrudes the LGU south of the Rodez orthogneiss. The three plutons present similar petrological and structural features. They 
experienced a heterogeneous deformation characterized by weakly deformed domains where equant structure is well preserved surrounded by mylonitic or ultramylonitic shear zones (Burg and Teyssier, 1983). Geochronological data are still rare. The zircon U/Pb date of $360 \pm 20 \mathrm{Ma}$ from the Pinet granite is interpreted as its emplacement age ( Pin, 1981) and the $346 \pm 7 \mathrm{Ma}{ }^{40} \mathrm{Ar} /{ }^{39} \mathrm{Ar}$ date on biotite is a considered as the deformation age (Maluski and Monié, 1988). According to previous works (Burg and Teyssier, 1983 and Burg et al., 1986) the Pinet pluton experienced a single tectonic episode contemporaneous with the dextral wrench-thrust.

\subsection{Structural pattern and kinematics}

The bulk geometry of eastern Rouergue is the result of two tectonic events referred to as D1 and D2. In the southern part of the study area, the D1 event is well preserved in the Paraautochthonous Unit where a south-vergent kilometer-scale recumbent syncline-anticline pair has been described (Guérangé-Lozes and Burg, 1990; Fig. 1). Northward, the initial geometry of the D1 event is also little disturbed by the later D2 tectonics. The early D1 flat-lying foliation bears N-S- to NE-SW-trending stretching and mineral lineations (L1), for instance in the Rodez orthogneiss and calc-alkaline granites ( Fig. 2 and Fig. 3). Shear criteria such as sigmoidal biotite or sigma-type porphyroclast systems indicate top-to-the-S or -SW displacements in agreement with the general nappe stacking kinematics of the French Massif Central. The L1 lineation and D1-associated kinematics are also well preserved along the western part of the Lévézou klippe despite the steepening of the foliation due to the D2 event.

In the Pinet wrench-thrust, the D2 top-to-the-NW shearing is responsible for the tectonic superposition of the Para-autochthonous Unit upon the LGU and the folding of the southern part of the D1 early contact between the Lévézou klippe and the Pinet granite. The S2 foliation bears a NW-SE (N110E-140E) L2 stretching lineation (Fig. 2 and Fig. 3). The prominent L2 NW-SE mineral and intersection lineation is defined by biotite and muscovite flakes arranged within the F2 fold axial surface. The F2 folds deform the earlier S1 foliation. Since F2 axial planes are parallel to the foliation and F2 fold axes are parallel to L2 stretching lineation, they are probably a-type folds formed during the top-to-the-NW D2 shearing. Locally, along the 'Pinet wrench-thrust fault', sheath folds with NW-SE-trending axes have been described (Burg and Teyssier, 1983). In thin sections cut parallel to the lineation and perpendicular to the foliation, quartz and biotite pressure shadows around garnets and shear bands indicate a top-to-the-NW shear sense. All the macroscopic and microscopic criteria support a non-coaxial flow regime for the D2 deformation ( Passchier and Trouw, 1998). Near the Pinet wrench-thrust, the structural pattern is complex. In the eastern part of the study area, for instance along the Tarn River, the northward dipping $\mathrm{S}_{1-2}$ foliation of the Paraautochthonous Unit progressively steepens when going northward. The NW-SE-trending foliation becomes subvertical and is inverted and then dips southwestward. 


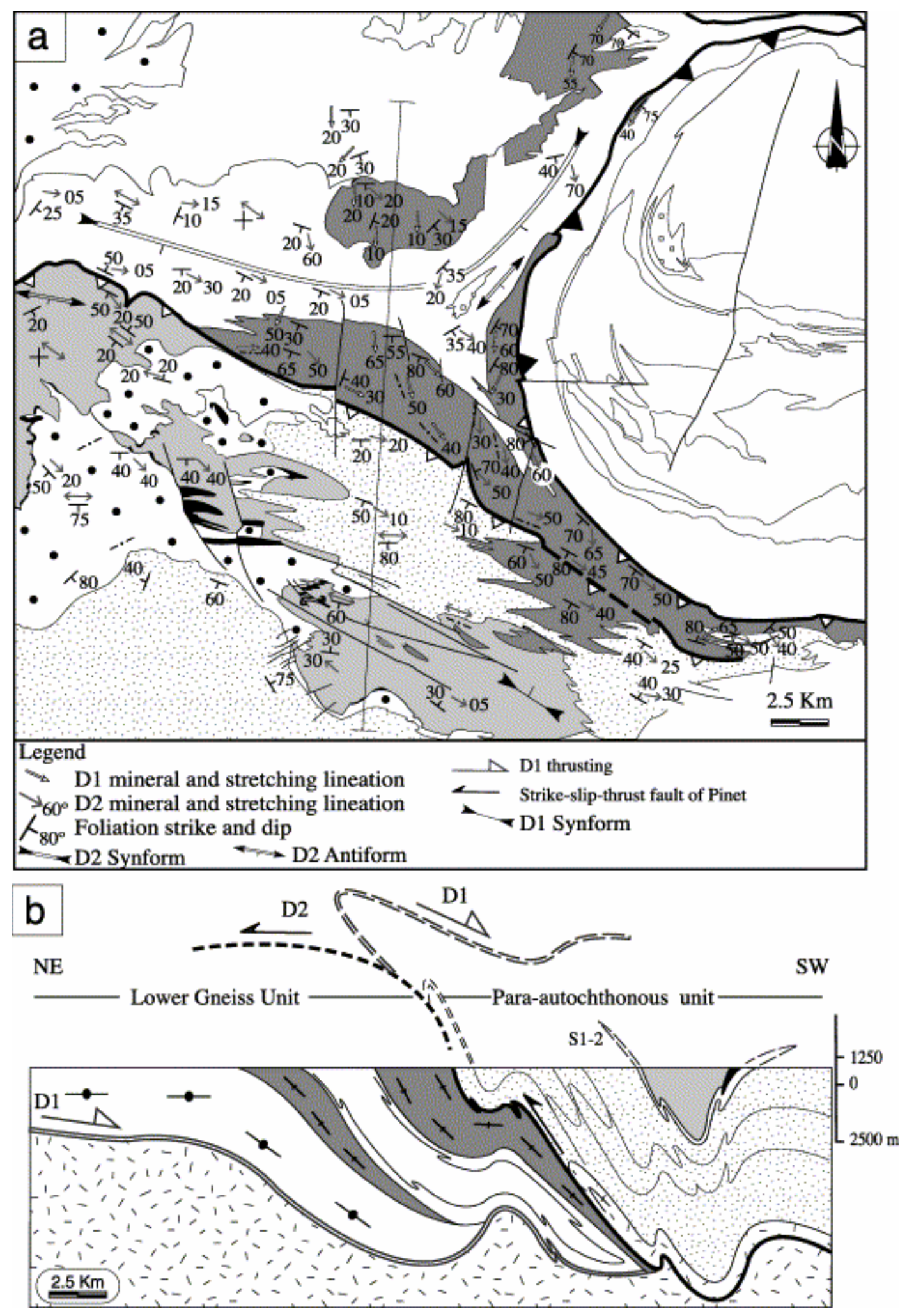

Fig. 2. (a) Structural map of foliations and lineations. (b) Interpretative cross-section of the Eastern Rouergue area (located on the geological map), showing the succession of the two deformations. During D1, the Lower Gneiss Unit overthrusts the Para-autochthonous Unit. D2 is a top-to-the-NW shearing that reworks the D1 foliation. Legend is the same as in Fig. 1. 


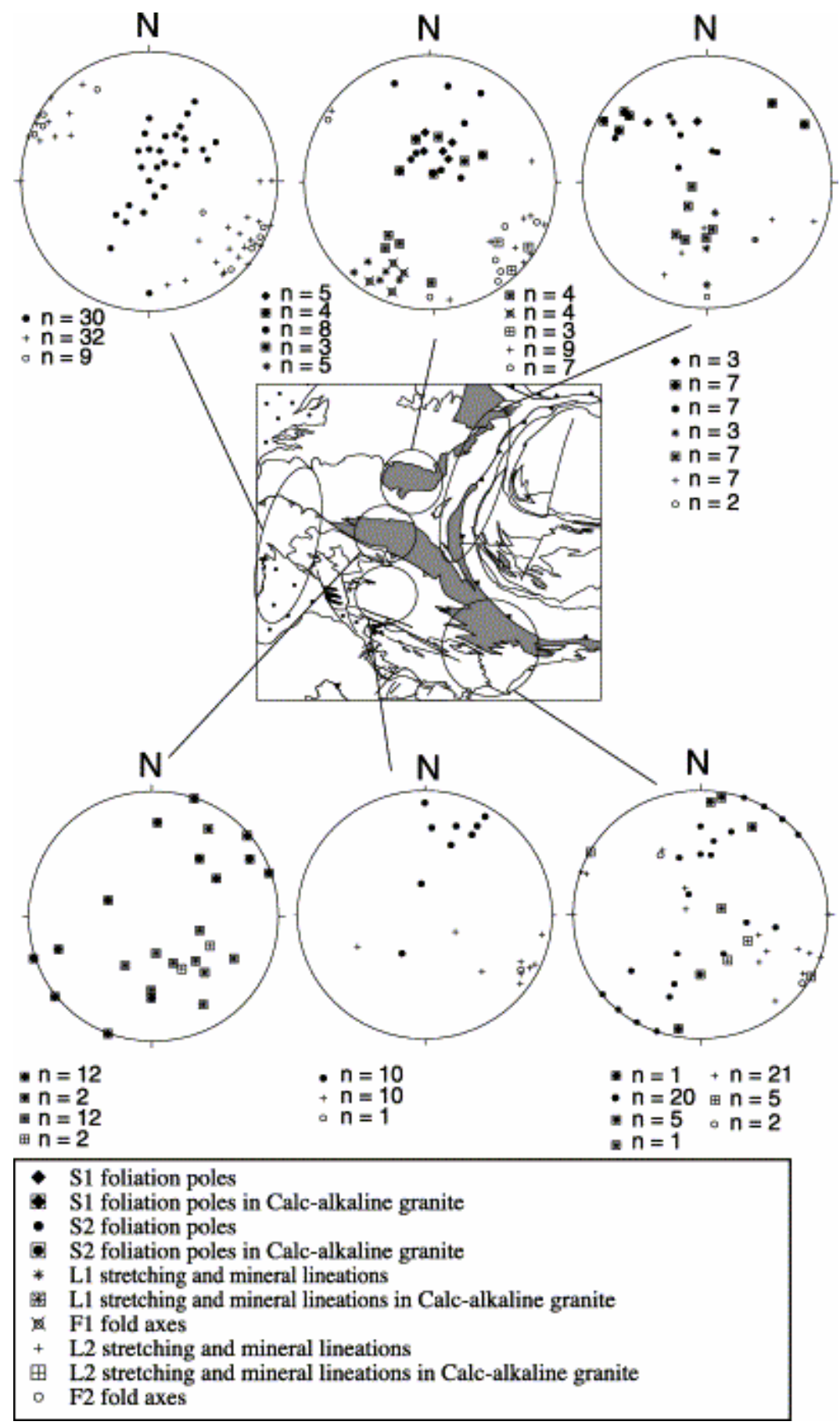

Fig. 3. Poles to foliation, fold axes, stretching and mineral lineations of D1 and D2 phases. Stereograms are lower hemisphere, equal-area (Schmidt) projections.

To the west, the $\mathrm{S}_{1-2}$ foliation is generally flat-lying or gently southward dipping in the Paraautochthonous Unit, the Lower Gneiss Unit and the granitoids. Therefore, in the Rouergue area, the Para-autochthonous Unit, which is normally overthrust by the LGU elsewhere in the Massif Central, overlies the LGU. Consequently, the southern part of the LGU is partly overturned and forms a northwest verging kilometer-scale recumbent synform developed 
during D2 (Fig. 2). This structural pattern complies with the asymmetry of second order F2 folds that deform the foliation. To the NE of the study area, the foliation of the LGU trends $\mathrm{N}-\mathrm{S}$ or NE-SW and dips steeply eastward, and the axis of the D2 synform turns to the NE due to the inherited D1 sub-circular geometry of the Lévézou klippe (Fig. 2). Therefore, the D2 event corresponds to a northwest verging backthrusting event with a strong wrench component.

\section{Polyphase deformation in the Pinet-type granitoids}

The D1 and D2 tectonic phases described above in the metamorphic rocks are also observed in the Pinet-type plutons. Except in their undeformed parts, these granitoids exhibit conspicuous planar and linear fabrics characterized by biotite preferred orientation, stretched quartz aggregates and fractured feldspar.

The Comps-Trémouilles pluton exhibits a flat-lying or gently southward dipping mylonitic foliation attributed to the D1 event since it is concordant with the S1 foliation in the host rocks. Where this foliation is not reworked by the D2 event, N-S to NE-SW conspicuous trending mineral and stretching lineations, correlated with L1, are underlined by the quartz ribbons, biotite clots and K-feldspar alignments. At the outcrop and hand-sample scales, numerous shear criteria such as $\mathrm{S}-\mathrm{C}$ structures or sigma-type porphyroclast systems indicate a top-to-the-S or -SW shearing. In thin sections parallel to the L1 stretching lineation and perpendicular to the foliation (i.e. along the $X Z$ plane of the finite strain ellipsoid) muscovite and biotite micafish, asymmetrical ribbon-quartz and sigma-type feldspar porphyroclasts comply with the southwestward shear sense determined in the field (Fig. 4). In agreement with observations in the host rock, the D2 event is rarely expressed in the Comps-Trémouilles pluton.

In the Pinet gneissic granite, the planar and linear fabrics exhibit a more complex geometry. In the eastern part of the area, the $\mathrm{S}_{1-2}$ foliation is dominantly subvertical and often dips at a high angle to the SW. On the basis of field observations, for instance along the Tarn River (Fig. 1 and Fig. 2), the foliation in the Pinet pluton appears concordant to that in the host rocks. The subvertical orientation results from a progressive tilting of the $\mathrm{S} 1$ foliation that was formed with an initial flat-lying attitude. As mentioned above, when moving westward along the Pinet massif, this steeply dipping foliation flattens. However, the flat-lying attitude is not the primary geometry but corresponds to the upside-down of the pluton. Consequently, in the western part of the Pinet massif, the southward dip of the foliation is due to a secondary northwestward overturning and shearing during the D2 event ( Fig. 2b). The upside-down geometry complies with the host rock structure presented in Section 2 and also with the kinematics inferred from the lineation pattern. Two generations of mineral and stretching lineations with various orientations are developed in the Pinet pluton. The most widespread lineation trends NW-SE (N110-140E) with plunges varying from 40 to $60^{\circ}$ eastward whatever the subvertical or flat-lying attitude of the foliation. Shear bands reworking the foliation are observed both in the field (Fig. $4 \mathrm{f}$ and $\mathrm{g}$ ) and under the microscope. Depending on the subvertical or flat-lying attitude of the foliation, the shear bands asymmetry indicates a right-lateral or top-to-the-NW shear, respectively. We interpret these shear bands as D2 centimeter- to meter-scale shear zones that rework the early S1 foliation under low to moderate temperature conditions. So, the shear bands are not S-C structures which may develop simultaneously in granites (e.g. Burg and Laurent, 1978 and Berthé et al., 1979). The post folial kinematics is relevant to the $\mathrm{D} 2$ northward-directed backthrusting described in the preceding section in the Pinet pluton host-rocks. 

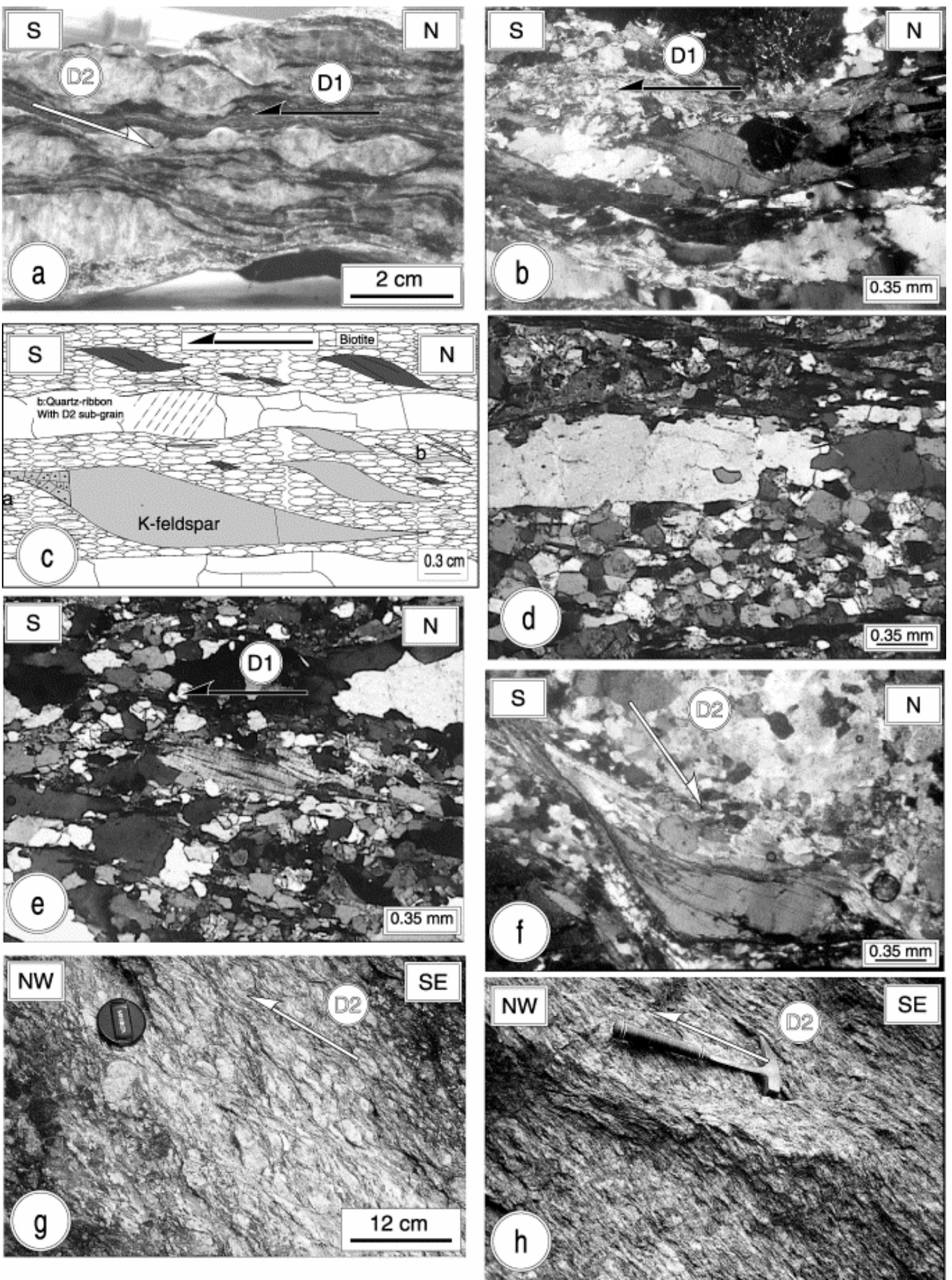

Fig. 4. Photographs and photomicrographs showing polyphase deformation in the calc-alkaline granites. (a) D1 high-temperature mylonite reworked by D2 top-to-the-NW shear bands. This hand-sample is located in the southern flank of the Lévézou klippe and belongs to the Pinet granite. (b) In the same sample, microscopic view showing sheared biotite giving a top-to-the-SW shearing. (c) Sketch illustrating the microstructure of the same mylonite. (d) Photomicrograph of the previous sketch drawing. This microstructure displays a straight polycrystalline quartz ribbon in alternation with layers of recrystallized feldspar. (e) D1 related muscovite micafish giving a top-to-the-SW shear sense. (Sample located on the Arvieu Pluton.) (f) D2 micro-shear bands with a top-to-the-NW sense of shear in the Pinet granite. (g) Outcrop view of D2 top-to-the-NW shear bands in the Pinet granite. (h) Outcrop view of D2 shear bands reworking a D1 mylonitic foliation in the Trémouilles pluton. 
Despite of the widespread development of the D2 backthrusting, an older L1 stretching lineation, characterized by a N-S or NE-SW trend is also recognized in the Pinet granitoids. Shear criteria such as micafish (Lister and Snoke, 1984) and sigma-type porphyroclast structures observed at the macroscopic- and microscopic-scales indicate a top-to-the-SW shearing ( Fig. 4a and b). Nevertheless, some outcrops show top-to-the-SE shear-senses along a NW-SE-trending lineation. By comparison with the structures observed in the CompsTrémouilles granite, we argue that this top-to-the-SE shearing does not correspond to a sinistral strike-slip event but rather to the D1 thrusting event with an initial flat-lying foliation and a NE-SW-trending stretching lineation. As shown by equal area projections in Fig. 5, the early L1 NE-SW-trending lineation can be rotated to a steeply dipping NW-SE-trending lineation after the D2 backthrusting event. In this case, the study of the kinematics and microfabrics is necessary to allow us to distinguish the two events. Due to its small size and poor outcrop conditions, the Arvieu pluton is less studied than the Comps-Trémouilles and Pinet massifs; nevertheless, similar planar and linear microstructures are recognized in this pluton. The granite foliation is steeply dipping eastward and bears a $\mathrm{N}-\mathrm{S}$-trending lineation related to D1. In conclusion, conversely to previous works (Burg and Teyssier, 1983 and Burg et al., 1986), the Pinet granites cannot be considered as syntectonic plutons coeval with the D2 Pinet wrench-thrust fault since field and hand sample structures show that the pluton architecture is not a primary one but is due to a secondary reworking. The microfabrics and quartz lattice preferred orientations presented in the following section support our interpretation. 


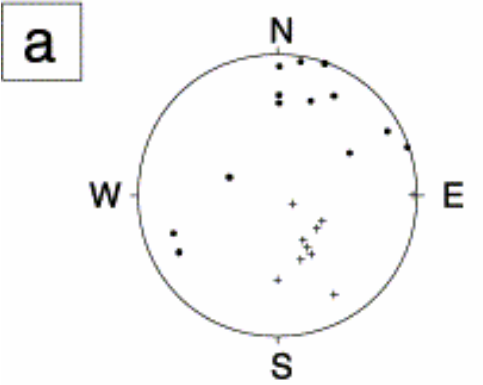

Pinet foliated granite Present geometry

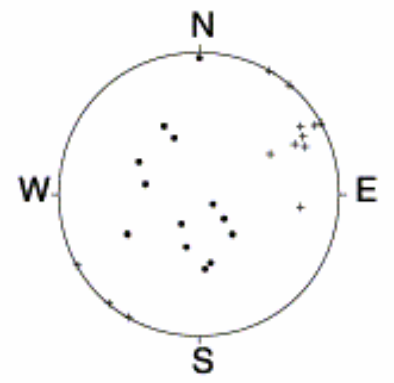

Pinet structures geometry before the D2 episode

Equal area projection, lower hemisphere

$+\mathrm{n}=12 ; \mathrm{L} 1$

- $\mathrm{n}=14 ; \mathrm{S} 1$
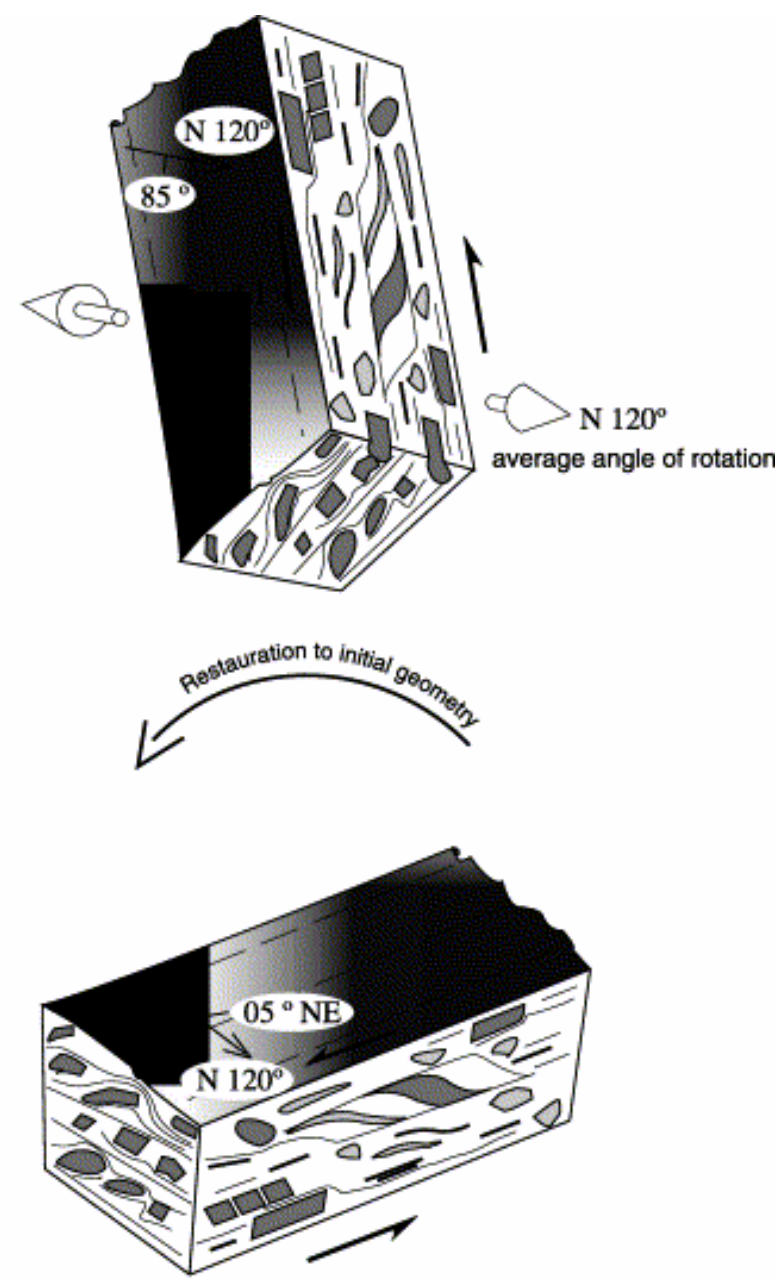

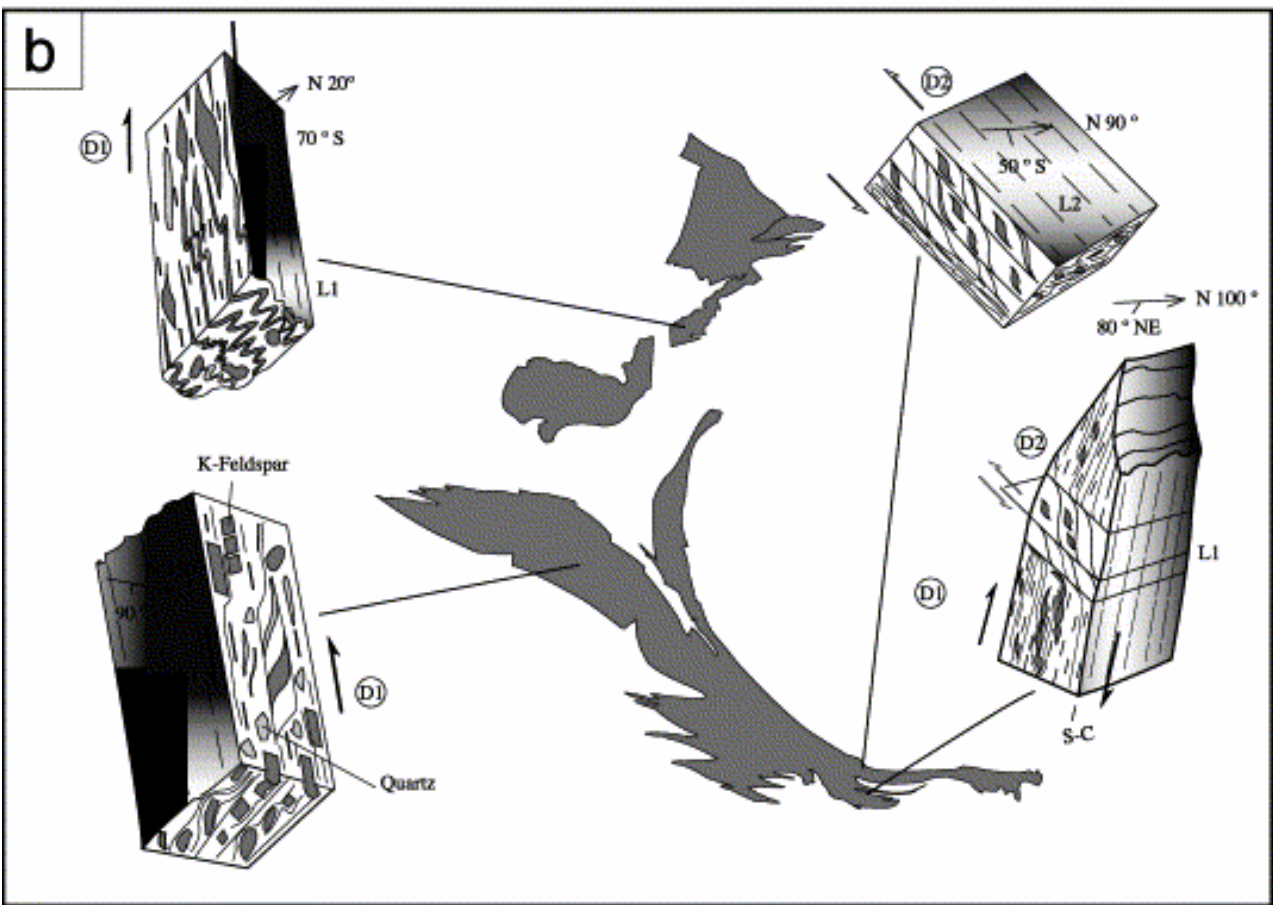

Fig. 5. Stereonets and block diagrams showing the geometric relationships between the D1 and the D2 events. In the Pinet granite, the initial D1 flat-lying foliation and the NE-SW-trending stretching lineation with a top-tothe-SW shear sense became a sub-vertical foliation with a NW-SE-trending strongly plunging lineation and an apparent sinistral shear sense. 


\section{Pre-full crystallization state and solid-state deformations in the Pinet-type plutons}

It is generally acknowledged that lattice preferred orientation development and activation of particular slip systems are mainly dependant on ambient temperatures (Jessell et al., 1990), strain rates and progressive deformation regime ( Lister and Hobbs, 1980; Etchecopar and Vasseur, 1987 and Law, 1990). Thus, in order to confirm the deformation mechanisms of the Pinet-type plutons and the kinematics of D1 and D2 events, studies of quartz $\langle c\rangle$ axis and textural relationships were undertaken. Quartz lattice preferred orientations have been measured by universal stage and by X-ray texture goniometry. The data are summarized in Fig. 6 and Fig. 7. The textural relationships and microstructures linked to the D1 and D2 events are successively examined. The chosen samples correspond to the deformed and less deformed facies representative of the whole history, from pre-full crystallization to postsolidus stages of granite emplacement and post-emplacement deformation. For $(m\rangle$ and $\langle a\rangle$ pole figures, contours at $1,3,5$, and 10 uniform distribution. PF11S sample: for $\langle 104\rangle$ pole figures, contours at $1,3,5$, and 10 uniform distribution. For $\langle m\rangle$ and $\langle a\rangle$ pole figures, contours at 1,3 , and 5 uniform distribution. 


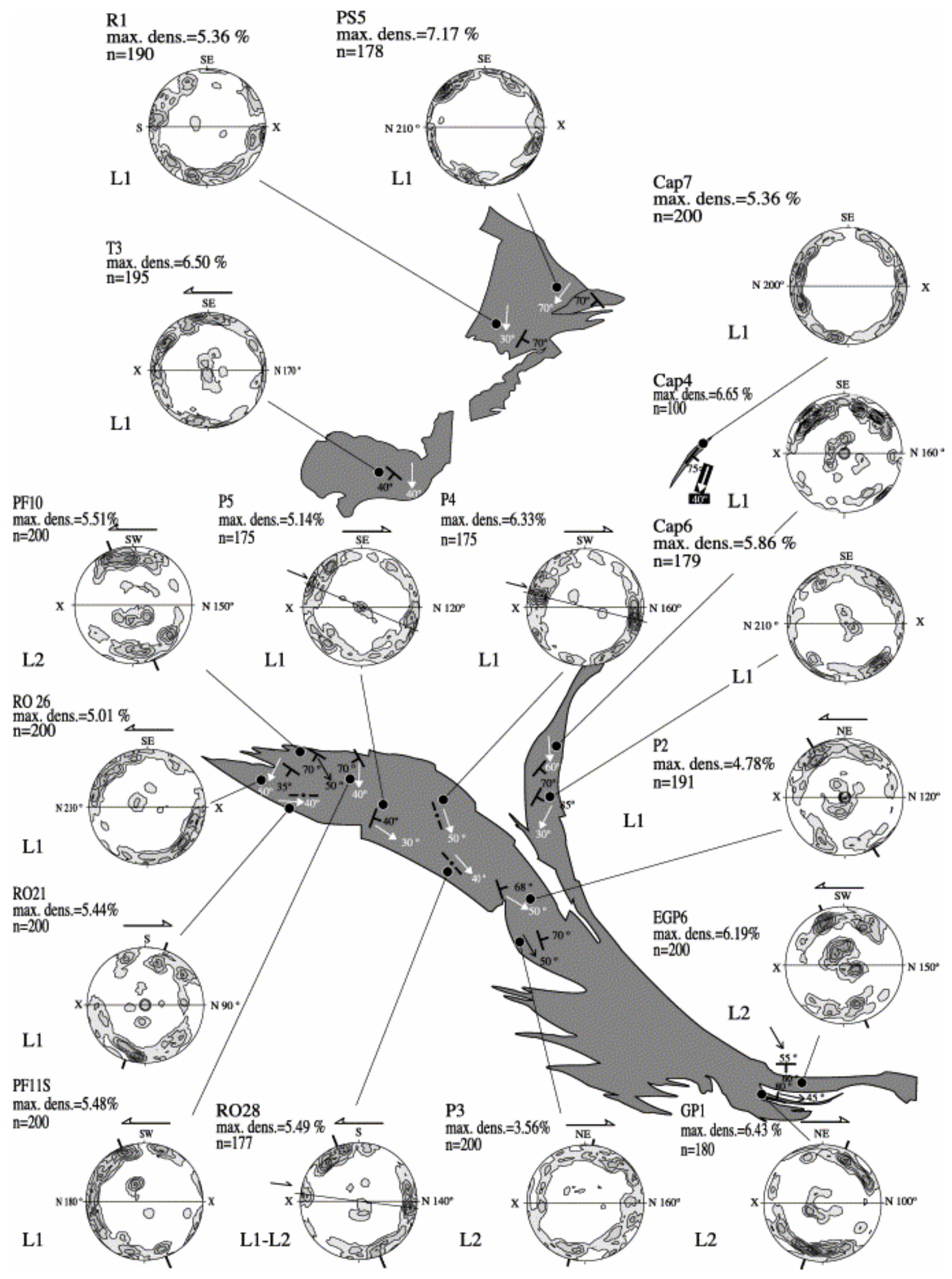

Fig. 6. D1 top-to-the-SW and D2 top-to-the-NW kinematic data observed in the Pinet-type granites. Quartz $\langle c\rangle$ axis sub-fabrics. Universal stage measurements are plotted on Schmidt lower hemisphere nets. Contours are at 1 , 2,3 and $4 \%$ for $1 \%$ area. 


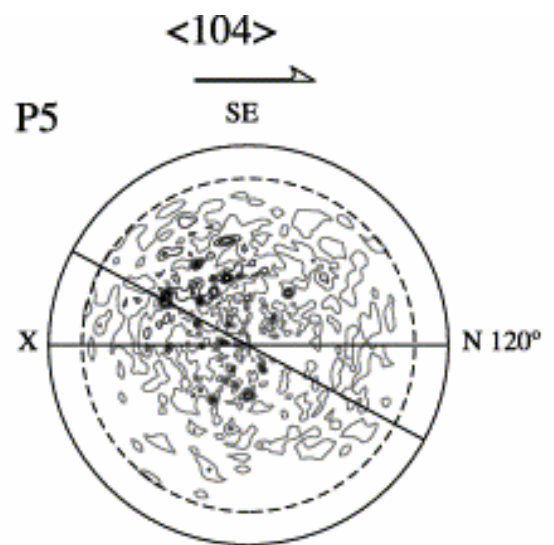

Max 13.34

SW

P4

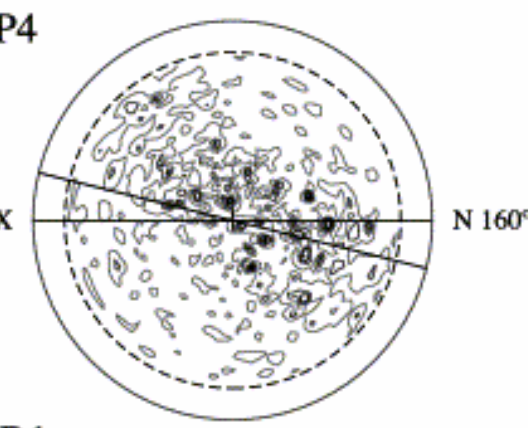

R1

Max 17.33

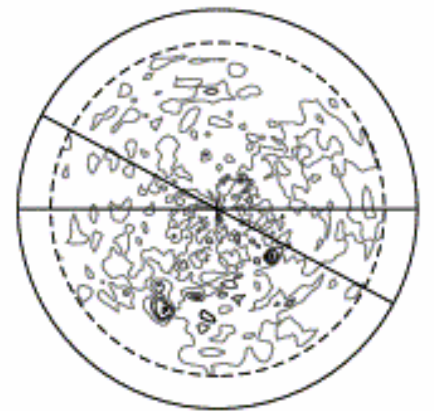

Max 15.62

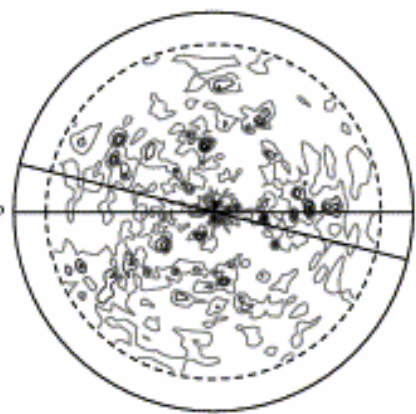

Max 21.20
$<100>$

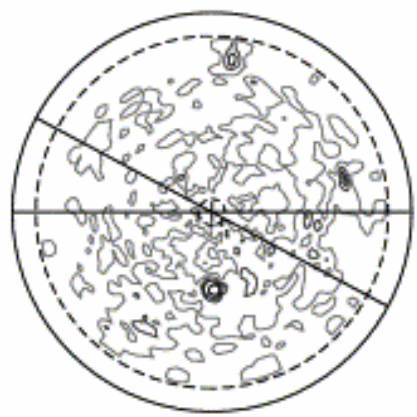

$\operatorname{Max} 16.8$
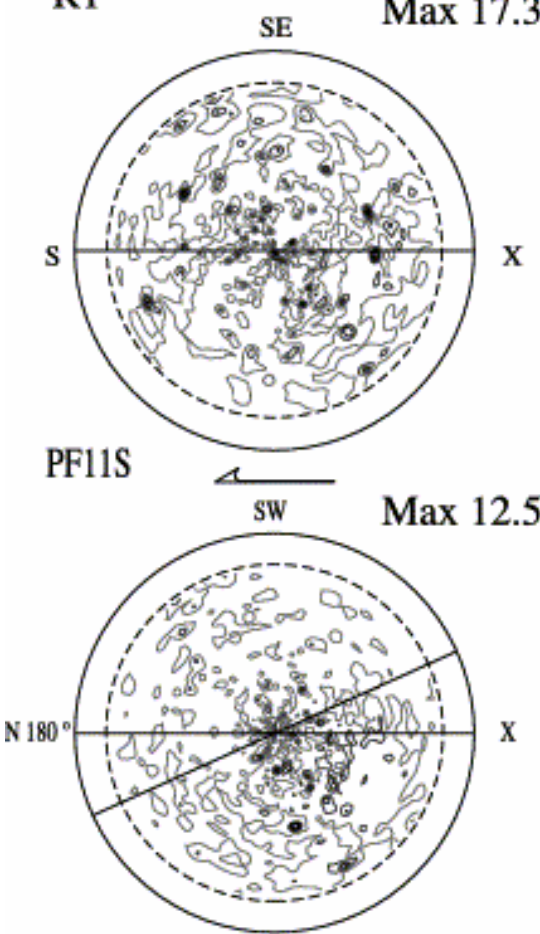

$\operatorname{Max} 18$

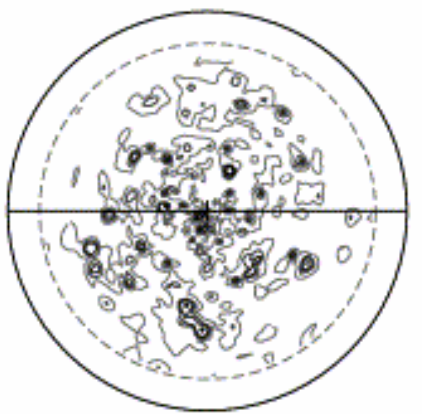

Max 32

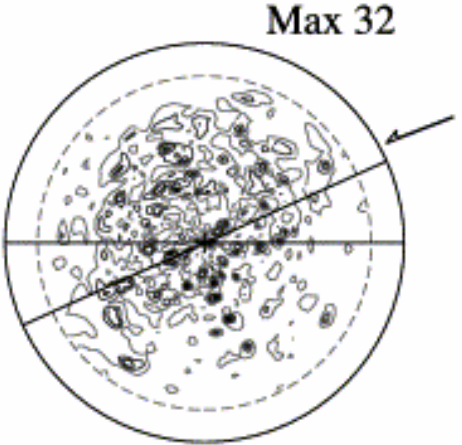

Max 6.33

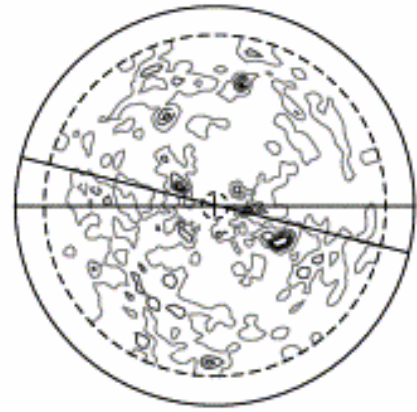

Max 9.71

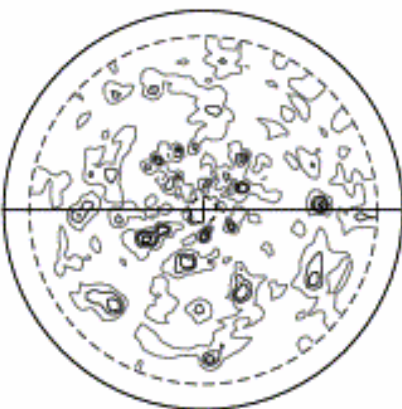

$\operatorname{Max} 16$

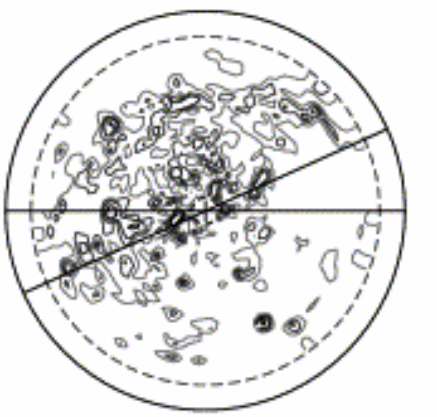

$\operatorname{Max} 8$

Fig. 7. $\langle c\rangle,\langle a\rangle$ and $\langle m\rangle$ axis preferred orientation fabrics realized by X-ray texture goniometry in samples where the D1-related deformation is dominant. P5 sample: for $\langle 104\rangle$ pole figures, contours at 1, 3, 5, and 8 uniform distribution. For $\langle a\rangle$ and $\langle m\rangle$ pole figures, contours at 1, 3, 5, and 10 uniform distribution. P4 sample: for $\langle 104\rangle$ and $\langle a\rangle$ pole figures, contours at 1, 3, 5, and 10 uniform distribution. For $(m)$ pole figures, contours at $1,3,5$, and 7 uniform distribution. $R 1$ sample: for $\$ 104\rangle$ pole figures, contours at $1,3,5$, and 7 uniform distribution. 


\subsection{The early D1 high-temperature top-to-the-SW event}

\subsubsection{The Pinet granite}

As shown above, many outcrops in the Pinet granite preserve evidence of the D1 event. For instance, along the southern boundary of the Upper Gneiss Unit, the Pinet granite displays an NW-SE-trending subvertical or steeply north dipping mylonitic fabric. The mineral and stretching lineations plunge to the NE (higher than $65^{\circ}$ ). Shear criteria show a top-to-the-SW sense of shear (Fig. 4a and b). Macroscopically, the samples are striped gneiss and under the microscope, they exhibit textural characteristics of high grade mylonite such as alternation of fine-grained recrystallized feldspar layers and coarse-grained quartz ribbons ( Fig. 4c; Passchier and Trouw, 1998 and Hippertt et al., 2001). All studied samples with shear senses toward the southwest display the same petrographic characteristics. However, quartz $(c)$ axis sub-fabrics measured on the samples show a conspicuous D2 overprint which partly erased the initial D1 $c$ ) axis pattern (Fig. 6).

Although the Pinet granite experienced the two regional tectonic events, the less deformed samples still display recognizable pre-full crystallization structures such as fluid relocation structures (Hibbard, 1987). Orthoclase crystals are surrounded by a fine-grained matrix of quartz and sodic plagioclase (albite, oligoclase). K-feldspars exhibit also albite exsolution lamellae characteristic of a high temperature recrystallization ( Paterson et al., 1989). Microaplites are also present in voids separating fractured K-feldspars. Such a structure is interpreted as a melt relocation process during the late stage of crystallization of a syntectonic granite (e.g. Hibbard, 1987 and Roig et al., 1996). Micro-aplites are also located in strain shadows or in shear bands around K-feldspars. They are characteristic of melt fraction migration at the pre-full crystallization stage of cooling in response to tectonic stresses.

The sample PF 11 (Fig. 8a) in which these features have been found displays two $\langle c\rangle$ axis maxima close to the stretching direction ( $X$-axis) but also close to the $Z$-direction. This $\langle c\rangle$ axis pattern suggests that prism $\langle c\rangle$ and basal $\langle a\rangle$ are the predominant intracrystalline slip systems that accommodate the deformation. This petrofabric pattern is interpreted as the coexistence of the two slip systems active at high temperature since no textural differences between prism $\langle c\rangle$ grains and basal $\langle a\rangle$ grains have been found (e.g. Bouchez et al., 1985 and $\underline{\text { Law, 1990)}}$. The significance of the quartz $\langle c\rangle$ axis pattern will be further discussed in Section $\underline{5}$. Our microscopic observations of sutured or lobate quartz grain boundaries in weakly elongated aggregates support this interpretation. Under the microscope, the quartz porphyroclasts also show a discrete undulose extinction and prismatic subgrain boundaries. Although no coherent shear sense can be deduced from the prism $\langle c$ glide system since the c) axis scatter on both sides of the $X$-direction, the basal $\langle a\rangle$ glide system which is responsible for the asymmetric fabric gives a top-to-the-SW shearing consistent with other shear criteria (Fig. 8a). The intracrystalline glide in the $\langle a\rangle$ direction on basal plane is also confirmed by the $\langle a\rangle$ axes pattern deduced from texture goniometry (Fig. 7). As expected in the basal $\langle a\rangle$ glide system, the $\langle a\rangle$ axes tend to cluster close to the shear plane and the shear sense deduced from the monoclinic symmetry is coeval with a top-to-the-SW shearing. 

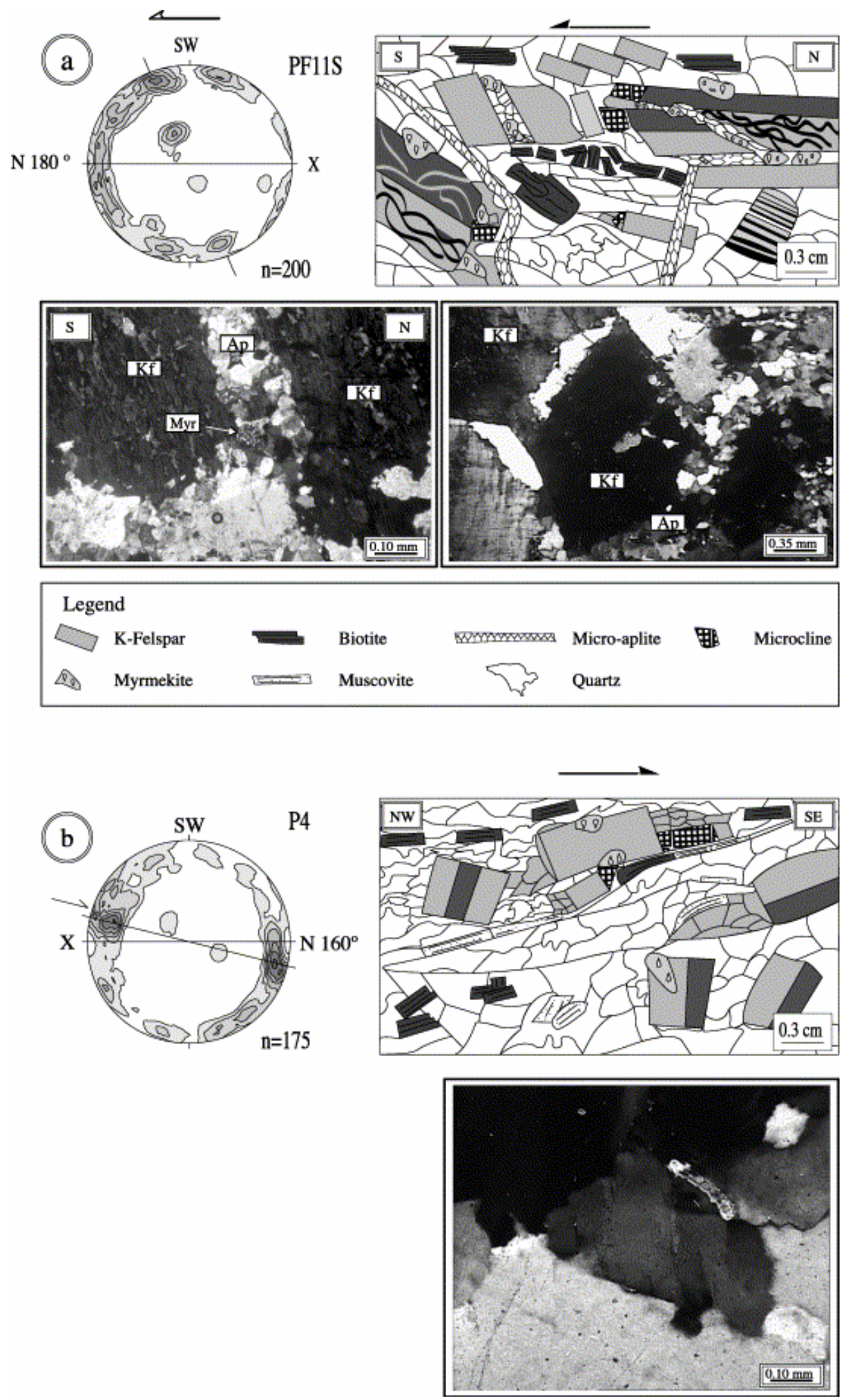

Fig. 8. Microstructure and quartz $\langle c\rangle$ axis fabrics related to the D1 top-to-the-SW kinematic event. (a) Synthetic sketch and microscopic views (crossed-polarized light) illustrating fluid relocation microstructures (sample PF 11, Pinet granite). (b) Synthetic sketch and quartz $\langle c\rangle$ axis fabrics associated showing the D1 high-temperature deformation (sample P4, Pinet granite). Notice the chessboard texture of quartz with basal and prismatic subgrains. 
Sample P4 (Fig. 8b) is a weakly deformed gneissic granite in which the foliation and the lineation are defined by the preferred orientations of feldspars and micas. The sample also displays some domains where solid state deformation overprints the early pre-full crystallization fabrics like pressure shadows around K-feldspars which locally present some undulose extinction and microcline recrystallization. The $\langle c\rangle$ axis pattern shows maxima close to the stretching lineation. The $\langle m\rangle$ axes concentrate perpendicular to the shear plane with sub-maxima close to $Z$ and $Y$. The quartz microstructure consists of polycrystalline aggregates or more rarely quartz ribbons (grain sizes from $750 \mu \mathrm{m}$ to $3 \mathrm{~mm}$ ). Samples PF 11 and P 4 present coarse grains with serrated and lobate boundaries in which prismatic and basal subgrain boundaries are observed. It is therefore likely that since the prism glide system is the dominant one, the deformation took place at $700-800{ }^{\circ} \mathrm{C}$ with high water content (Blumenfeld et al., 1986 and Mainprice et al., 1986). The fabric asymmetry indicates a top-tothe-SE shear sense consistent with the shear sense given by the other criteria.

In contrast to the previously discussed samples, the $(c)$ axis pattern interpretation of the sample RO 26 is more difficult to link to the kinematic framework. Sample RO 26 is a mylonite that displays an alternation of recrystallized K-feldspar layers and polycrystalline quartz ribbons. The foliation is well defined, which suggests that this rock is a $\mathrm{S}>\mathrm{L}$ tectonite. The kinematic criteria are consistent with a top-to-the-SW shearing likely related to the D1 event. The $(c)$ axes are distributed in three maxima which are disposed in the following way (Fig. 9a): a main maximum at $45^{\circ}$ to the lineation ( $X$ axis of the finite strain ellipsoid), a secondary maximum close to the $Z$ axis, and a third one near the $X$ axis. The maxima close to the $X$ and $Z$ axes suggest either the coeval activation of the prism $\langle c\rangle$ and basal $\langle a\rangle$, respectively, or a switch between prism $\langle c\rangle$ to basal $\langle a\rangle$ during the deformation and the cooling of granite. However, the maximum at $45^{\circ}$ to the lineation remains to be explained. The optical microscopic examination of quartz microstructure allows us to recognize Grain Boundary Migration (GBM) microstructures. Irregular grain shapes, lobate and concave/convex grain boundaries, 'pinning windows' structures are usually admitted as being characteristic of a high mobility of the grain boundary at high temperature and low strain rate (Jessell, 1987; Fig. 9a). Therefore, the highly oblique maximum would be the result of a GBM process which consists of a consumption of 'hard' grain orientation with high dislocation density (maxima close to the $X$ and $Z$ axes) to the benefit of 'soft' grain orientation (Neumann, 2000). Dynamic recrystallization seems to be the dominant process in the development of the quartz microstructure. However, the maximum close to the $Z$-axis and the resulting asymmetric fabric is consistent with an activation of the basal $\langle a\rangle$ glide system and the other shear criteria which give a top-to-the-SW shearing. 

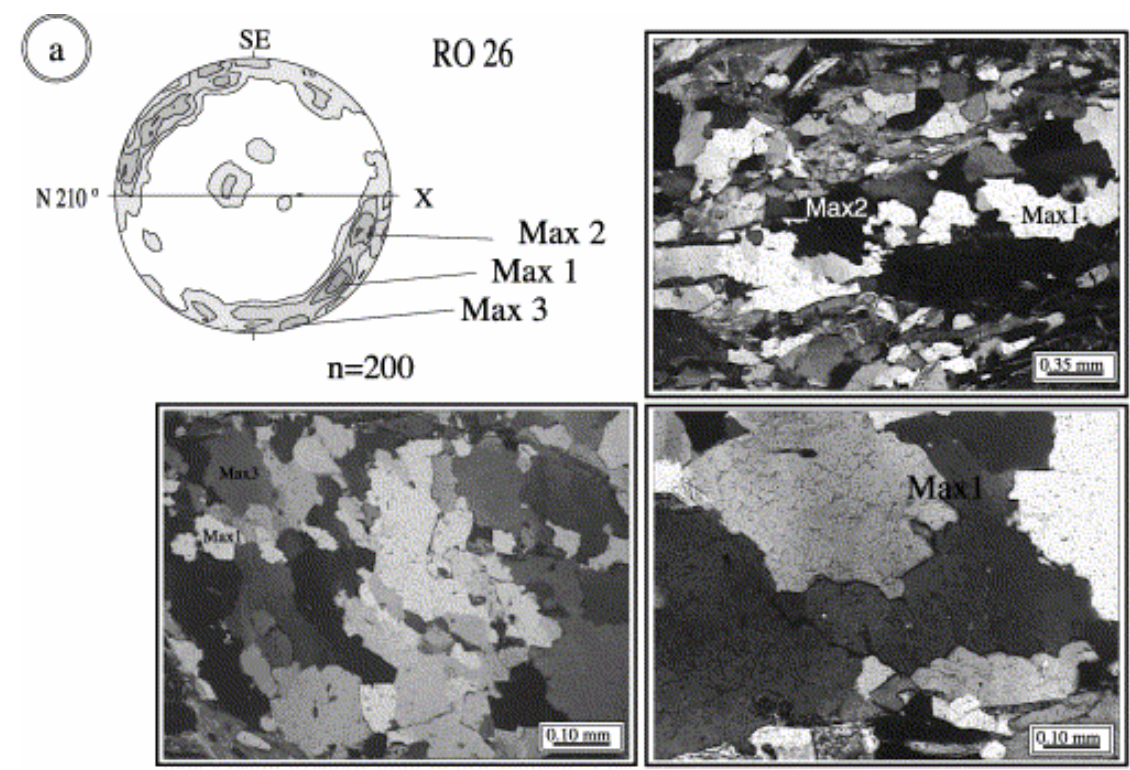

(b)
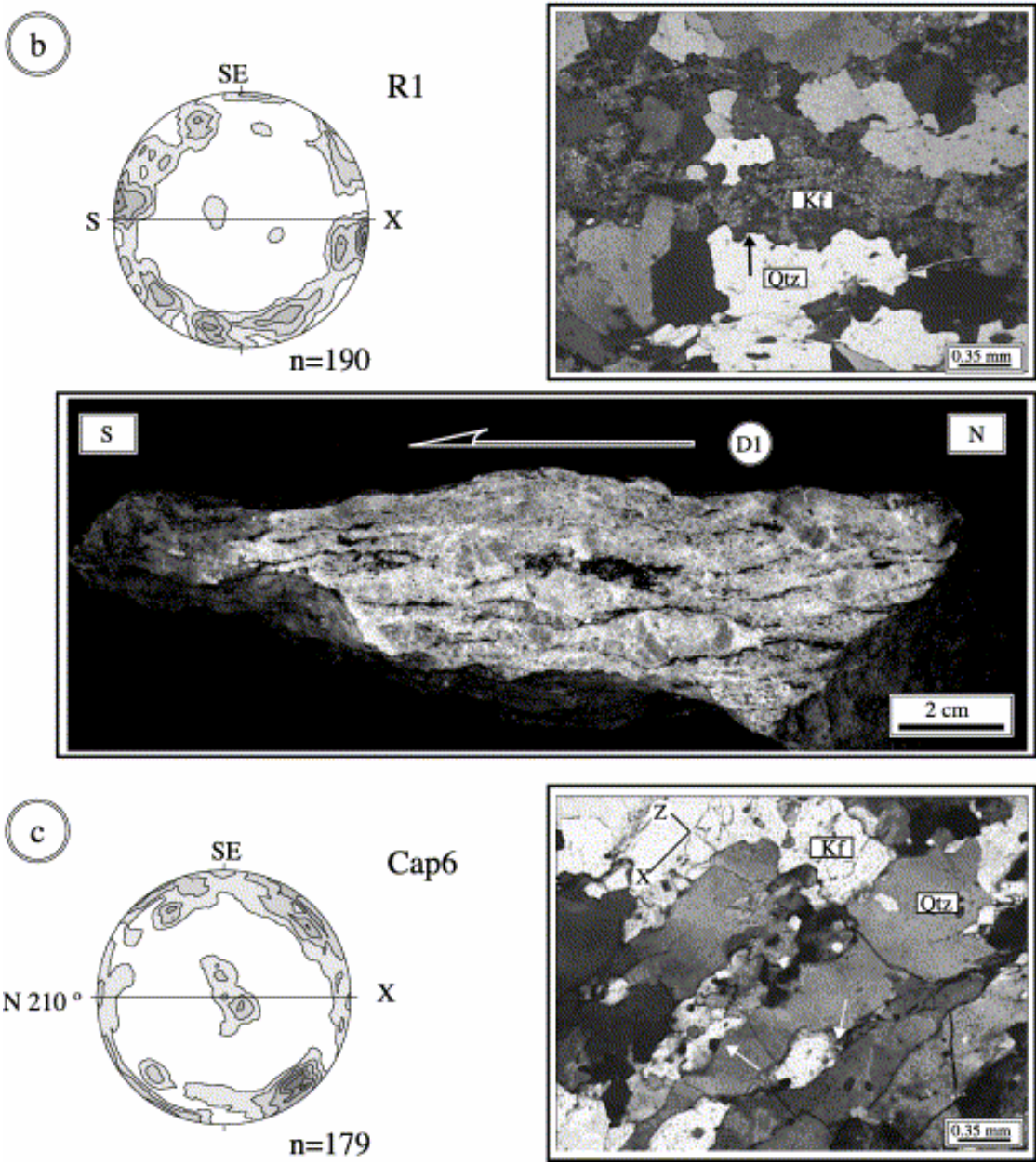

Fig. 9. Microstructure and quartz $\langle c\rangle$ axis fabrics related to the D1 top-to-the-SW kinematic event. (a) Example of recrystallization process by GBM during the D1 event. The quartz fabric acquired during the deformation is incompletely erased (sample RO 26, Pinet granite). (b) Quartz $(c)$ axis fabrics and microstructures showing quartz-feldspar phase boundary morphologies. This phase boundary motion (underlined by the black arrows) results from a diffusion-assisted process during the deformation. Notice that the asymmetry of the quartz $(c)$ axis fabric patterns is not consistent with the shear sense deduced in the hand sample (sample R1, Comps granite). (c) Example of high-temperature fabric and diffusion-assisted process in the Arvieu laccolite (sample Cap 6). 
The significance of the maximum near the $X$-axis is more ambiguous since the shear sense deduced from the fabric asymmetry is not consistent with the macroscopic one. A possibility to explain this discrepancy would be to consider that a small amount of coaxial flow combined with the dominant non-coaxial flow is responsible for the quartz $\langle c\rangle$ axis sub-fabric. In this perspective, Garbutt and Teyssier (1991) have described the rotation of the maximum related to the prism $\langle c\rangle$ glide system modifying the initial geometrical relationship between the lineation and the quartz $c$-axes maxima related to prism $\langle c\rangle$ glide system during a transition between prism $\langle c\rangle$ and basal $\langle a\rangle$ in a single kinematic event. According to the amount of rotation, the shear-sense deduced from the quartz petrofabric will be a wrong one. The high temperature crystallographic fabrics coeval with a top-to-the-SW shear sense observed in thin section, sample and outcrop scales and the pre-full crystallization to solidstate textural associations displayed here lead us to infer that the emplacement of the Pinet granite is contemporaneous to the D1 nappe stacking event.

\subsubsection{The Comps-Trémouilles and Arvieu gneissic granites}

In contrast to the Pinet granite, these plutons present widespread foliation and lineation fabrics. In the Comps-Trémouilles and Arvieu gneissic granites, two main types of fabric are described below in relation to deformation mechanisms, namely oriented crystal growth and dynamic recrystallization of preexisting porphyroclasts.

The first type of $\langle c\rangle$ axis subfabric displays maxima close to the stretching lineation with secondary maxima close to the $Z$ axis (R1 sample) or placed symmetrically to each side of the stretching lineation (Cap 7; Fig. 6). These preferred orientation patterns suggest that prism $\langle c\rangle$ slip was activated (Blumenfeld et al., 1986). Nevertheless, for the R1 sample, the shear sense deduced from the petrofabric does not confirm the shear sense given by sigmoidal micas and sigma-type porphyroclast systems. Moreover the complexity of $\langle a\rangle$ and $\langle m\rangle$ axes patterns does not allow us to draw a conclusion on the activated intracrystalline slip system. At the macroscopic scale, sample R1 shows a mylonitic foliation with parallel $\mathrm{C}$ and $\mathrm{S}$ surfaces. The NE-SW L1 lineation is a stretching lineation due to the preferred orientations of biotite and muscovite crystals with euhedral shape and by elongated quartz aggregates. The K-feldspars are stretched in the $X$ direction of the finite strain ellipsoid and display asymmetric recrystallization tails giving a consistent top-to-the-SW sense of shear (Fig. 9b). At the microscopic scale, large quartz grains (average size from 2.5 to $4 \mathrm{~mm}$ ) with sutured or lobate boundaries, form polycrystalline aggregates and ribbons. Free dislocations and rare chessboard-like microstructures (characteristic of prism $\langle c\rangle$ slip system) are also locally present. Sample Cap 7 shows the same textural relationships as those described for R1. The quartz $(c)$ axis subfabric characterized by weak maxima with the same intensity on each side of the maximum stretching direction does not allow us to deduce a consistent shear sense. Nevertheless, in this sample, asymmetric strain shadows around K-feldspars, and micafish of biotite and muscovite clearly show a top-to-the-SW shear sense.

The second petrofabric type is constituted by an orthorhombic symmetry of the $\langle c\rangle$ axis pattern (e.g. PS 5 and Cap 6 samples; Fig. 6). In these samples, the shear criteria give a consistent top-to-the-SW displacement. Nevertheless, the high angle (about $45^{\circ}$ ) between the first order $\langle c\rangle$ axis maximum and the $Z$ axis is difficult to link to an intracrystalline glide system even if basal $\langle a\rangle$ slip is considered. The case of sample Cap 4 is easier to discuss, since this rock presents unambiguous shear criteria with a top-to-the-SW shear sense. However, a few symmetrical porphyroclast systems around K-feldspar megacrysts suggest a coaxial flow. 
This observation complies with the orthorhombic symmetry of the quartz $\langle c\rangle$ axis sub-fabric pattern, which presents two maxima with the same intensity at $45^{\circ}$ on each side of the $Z$ axis (Lister and Hobbs, 1980 and Law, 1987). The coarse quartz microstructure presents grain sizes from 1.5 to $2.5 \mathrm{~mm}$. A possible explanation of the orthorhombic fabric symmetry of the sample Cap 4 would be related to strain partitioning at the microscale between quartz ribbons and K-feldspar porphyroclasts. Quartz ribbons and K-feldspar porphyroclasts record, respectively, the coaxial and non-coaxial components of the strain.

The kinematic criteria identified in all samples presented above (R1, Cap 7, Cap 6 and Cap 4), do not reflect the same apparent kinematic path as the quartz $\langle c\rangle$ axis subfabrics. The discrepancies between the shear-sense deduced from shear criteria and the quartz lattice preferred orientations are difficult to relate only to a dynamic recrystallization process. A first element to solve this question may come from textural analyses and more particularly from the morphology of boundaries between quartz and feldspar grains. In samples R1 and Cap 6 presented in Fig. 9b and c, quartz-feldspar phase boundaries are curved and often present cuspate geometry. This quartz-feldspar morphology has already been described and explained as the result of solid-state diffusion-assisted processes of strain. However, the deformation processes described by Gower and Simpson (1992) occurred during a melt-free prograde metamorphism. In our case, this diffusion-assisted deformation mechanism occurs probably at the HT solid stage. The deformation in the quartz-feldspar polycrystalline aggregates, which took place under upper amphibolite facies conditions $\left(650-750{ }^{\circ} \mathrm{C}\right)$, was accommodated by both diffusion and dislocation creep. During the deformation, quartz-feldspar phase boundaries were highly mobile; feldspar dissolution was maximum along foliation-parallel phase boundaries while feldspar precipitation occurred along quartz-feldspar boundaries perpendicular to the foliation (i.e. along to boundaries parallel to the maximum finite shortening; Fig. 9). In the Comps-Trémouilles and Arvieu plutons, deformation played a significant role in the acquisition and development of these quartz-feldspar grain boundary morphologies. Nevertheless, at least for sample R1, we argue that dislocation creep remained a secondary process in the accommodation of the strain. The rectangular shape of the quartz grains and the mosaic-like pattern suggest a crystallographic control and high mobility of grain boundaries (Gapais and Barbarin, 1986). Prism $(c)$ glide system occurs classically under highly hydrous conditions (Blumenfeld et al., 1986 and Mainprice et al., 1986). In contrast, the activation of the basal $a\rangle$ glide system at very high temperatures is typical of anhydrous conditions (Hippertt et al., 2001), which is quite unexpected in magma with high water content. One possible explanation would be to consider that the different types of quartz fabrics represent local variations in fluid contents in granite.

In summary, the development of quartz petrofabrics resulted from three main mechanisms, namely: (i) preferential growth of quartz grains in the easy prism $k>$ slip during granite crystallization under strain; (ii) diffusion-assisted deformation at high temperature perhaps at the transition from pre-full crystallization state to HT solid state conditions; and (iii) high temperature solid-state deformation with intracrystalline prism $\langle c\rangle$ slip system. It is worth noting that the plastic strain mechanisms are not homogeneously distributed throughout the Comps-Trémouilles granite. Conversely to the Pinet granite where the top-to-the-SW deformation continued at lower temperatures allowing the basal $\langle a\rangle$ slip system to be activated, in the Comps-Trémouilles and Arvieu plutons, the top-to-the-SW event is achieved under high temperature only. The intracrystalline strain mechanism was not strong enough to rework the initial $\langle c\rangle$ axis preferred orientation acquired during the pre-full crystallization to high temperature solid stages along the main gliding direction (e.g. sample R1). 


\subsection{The D2 solid-state top-to-the-NW shearing}

As did the host rocks, the Pinet-type granitoids experienced the second D2 deformation. The D2 event is conspicuously developed in the Pinet granite where it clearly overprints the earlier high-temperature D1 event. The quartz microstructures and preferred orientations described below show that the D2 event was a heterogeneous and solid-state deformation. As shown above in Section 3 for the country rocks of the Pinet granite, kinematic indicators record a top-to-the-NW shear which is consistent with that deduced from the $\langle c\rangle$ axis subfabric pattern. The maxima close to the $Y$ - and $Z$-axes are attributed to the prism $\langle a\rangle$ and basal $\langle a\rangle$ systems that are the dominant glide systems (e.g. Burg and Laurent, 1978). In agreement with previous works dealing with fabric development, the activation of basal $\langle a\rangle$ and prism $\langle a\rangle$ slip occurs in the temperature range from 350 to $500{ }^{\circ} \mathrm{C}$ (Bouchez, 1977; Jessell and Lister, 1990 and Passchier and Trouw, 1998).

The 〈c〉 axes maxima asymmetry allows us to infer a non-coaxial deformation (Etchecopar and Vasseur, 1987 and Law, 1990). Examples of quartz microstructures developed during D2 are presented in Fig. 10. They display typical features of dynamically recrystallized quartz by subgrain rotation in which relics of large old grains with undulose extinction are surrounded by new fine grain polycrystalline aggregate with variable grain sizes from 25 to $250 \mu \mathrm{m}$. The subgrain rotation mechanism is expected to occur at a higher strain rate and lower temperature than grain boundary migration (Jessell and Lister, 1990). Moreover, even if some limited basal $\langle a\rangle$ glide occurred during the D1 event, numerous features are specific to the D2 event. For instance, K-feldspar porphyroclasts are deformed by fracturing, grain size reduction and replaced by sericite and muscovite (Fig. 10a). Such textural relationships demonstrate softening reactions during a low- to medium-grade mylonitic deformation in a granitoid ( Hippertt and Hongn, 1998). $\mathrm{K}^{+}$ions released during softening reactions are used to form muscovite within top-to-the-NW shear bands. In sample PF 10 (ig. 10), where top-to-theNW shear bands are consistently developed, the quartz $\langle c\rangle$ axis pattern clearly confirms the non-coaxial character of the deformation and the activation of the basal $\langle a\rangle$ slip system and to a lesser extent the prism $\langle a\rangle$ slip system. 
(a)
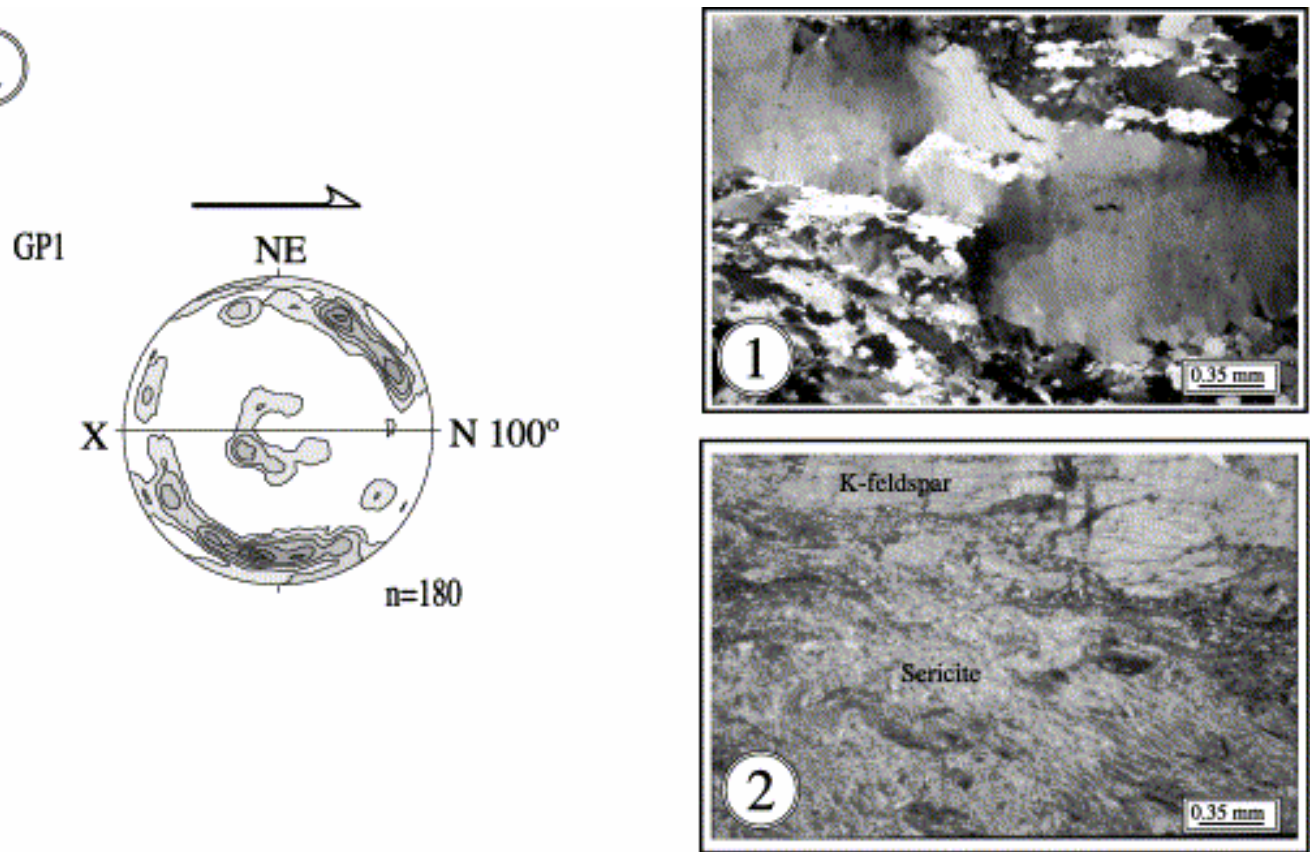

(b)

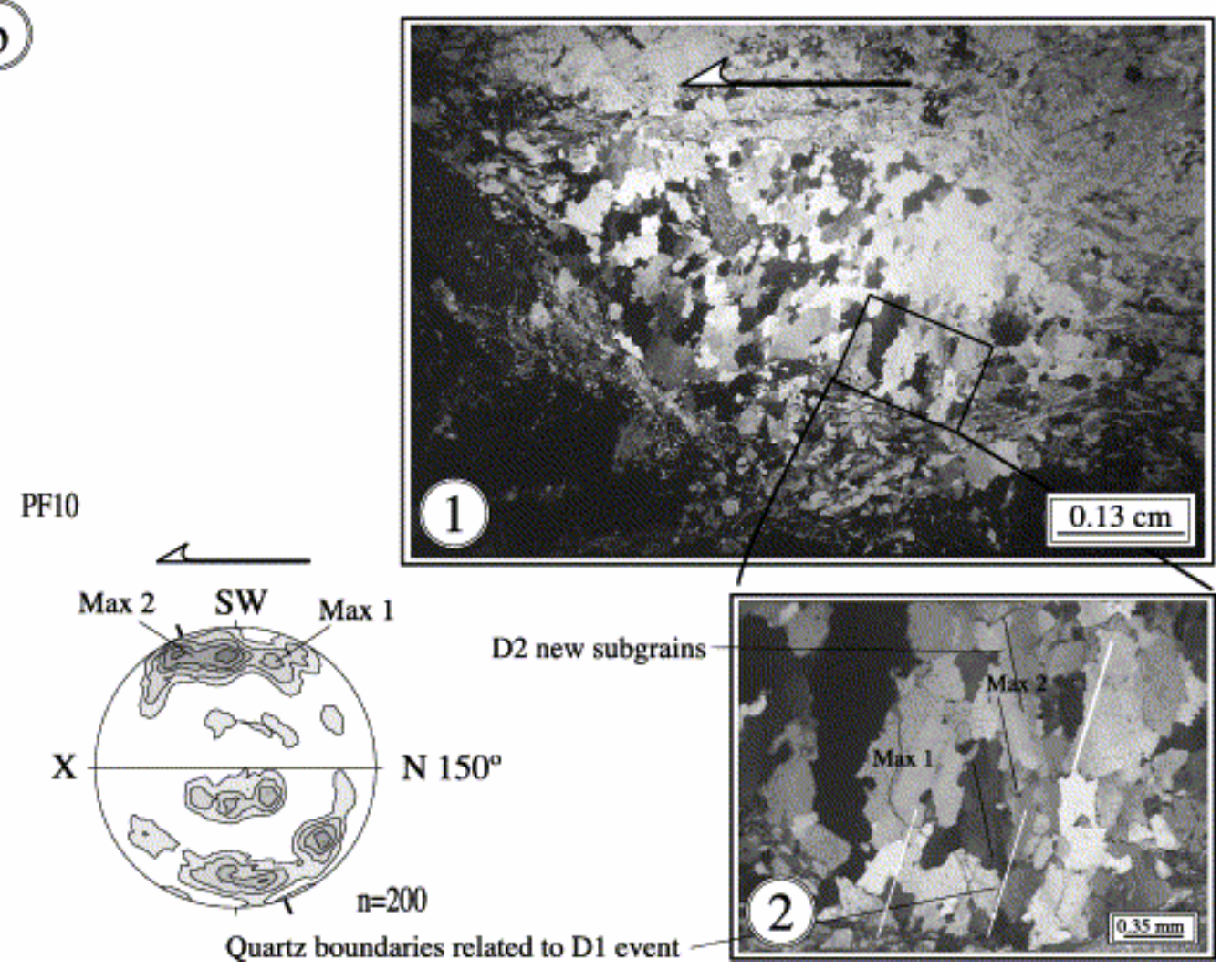

Fig. 10. Quartz $(c)$ axis fabrics related to the D2 event. (a1) Notice the porphyroclast with undulose extinction surrounded by new fine grain polycrystalline aggregate, typical of dynamically recrystallized quartz by subgrain rotation. (a2) Sericite replacing K-feldspar during the D2 event (Pinet granite). (b1) Quartz polycrystalline aggregate deformed by the D2 event. (b2) Detail microphotography of the previous view showing D1 recrystallized quartz grain with old subgrains reworked by the D2 event responsible of the formation of new subgrains (Pinet granite).

The quartz microstructure shown in Fig. 10 provides evidence for a polyphase deformation. The quartz grains composing the polycrystalline quartz aggregate present elongated shapes at a high angle to the foliation. The elongated quartz grains with well-sutured boundaries 
correspond to the weaker maximum (Max 1) close to the Z-axis (Fig. 10b). The stronger maximum (Max 2) is associated with quartz grains that display lobate boundaries. The quartz grains corresponding to Max 2, grow by grain boundary migration at the expense of Max 1 quartz grains. The top-to-the-NW event is responsible for the development of new subgrains and the misorientation of old quartz grains. Thus, Max 1 corresponds to an earlier inherited quartz $\langle c\rangle$ axis subfabric acquired during the top-to-the-SW event. Indeed, the quartz grain boundaries observed in Fig. 10b are old subgrains whose orientations are inconsistent with a top-to-the-NW intracrystalline slip. Moreover, the early quartz fabric pattern is partially erased by grain boundary migration, which accommodates the rotation of quartz grains during the D2 deformation and consumes the grains unfavorably oriented for easy-slip (Max 1).

\section{Discussion and conclusion}

The Pinet-type plutons display complex $(c)$ axis patterns that are related in this paper to polyphase deformation. The main feature of the quartz petrofabrics is the presence of maxima close to the $X$ and $Z$ directions, which reflect the activation of prism $\langle c\rangle$ and basal $\langle a\rangle$ glide systems. Whereas some samples, like RO 26, show a transition from the prism $\langle c\rangle$ to the basal (a) glide system during cooling of the granite, other samples (e.g. PF 11) display a simultaneous activation of both glide systems. This last process described in sample PF 11 has already been described (Bouchez et al., 1985) but no explanation has been proposed until now. As shown above in the Comps-Trémouilles and Arvieu plutons, the activation of prism ? $c\rangle$ or basal $\langle a\rangle$ glide systems depends mainly on the temperature but also on the amount of an aqueous fluid phase. Such a hypothesis may also account for the coexistence of both glide systems. A too small amount of water content would not allow the prism $(c)$ glide system alone to accommodate the deformation. Thus, the emplacement of the Pinet-type granites can be considered as syntectonic with respect to the D1 event. The quartz petrofabrics and textural relationships related to the D1 top-to-the-SW thrusting developed under pre-full crystallization to high temperature conditions. These crystallographic fabrics in quartz are coeval with melt relocation in partly crystallized granite in pre-full crystallization stage. This event is followed by a solid-state D2 event characterized by top-to-the-NW kinematics developed under middle pressure/middle to lower temperature metamorphic conditions.

The above-described pluton deformation history is replaced in the regional tectonic framework (Fig. 11). Contrary to previous works (Burg and Teyssier, 1983), which interpreted the Pinet-pluton emplacement as occurring during the D2 top-to-the-NW shearing, our data show that the Pinet-type granites emplacement was coeval with the top-to-the-SW shearing related to D1 nappe stacking. Indeed, the D2 thrust-wrench faulting reworked D1 fabrics both in the stack of metamorphic nappes and in the plutons. In the Pinet-type plutons, the D2 event refolded the earlier foliation formed during D1 and a NW-SE-trending stretching lineation developed. The two shear events are kinematically incompatible and they are certainly distinct in time. Nevertheless, the problem of exact timing of the D1 and D2 phases remains an important question for the understanding of the Hercynian orogeny in the southern Massif Central. Available ${ }^{40} \mathrm{Ar} /{ }^{39} \mathrm{Ar}$ ages around $360-350$ Ma for the deformed biotite of the Pinet pluton (Maluski and Monié, 1988) correspond to that of the D2 event. This date complies with radiometric ages from different parts of the French Massif Central ( Costa, 1992 and Faure et al., 2002). 
380 Ma ? : D1 top-to-the SW nappe thrusting event

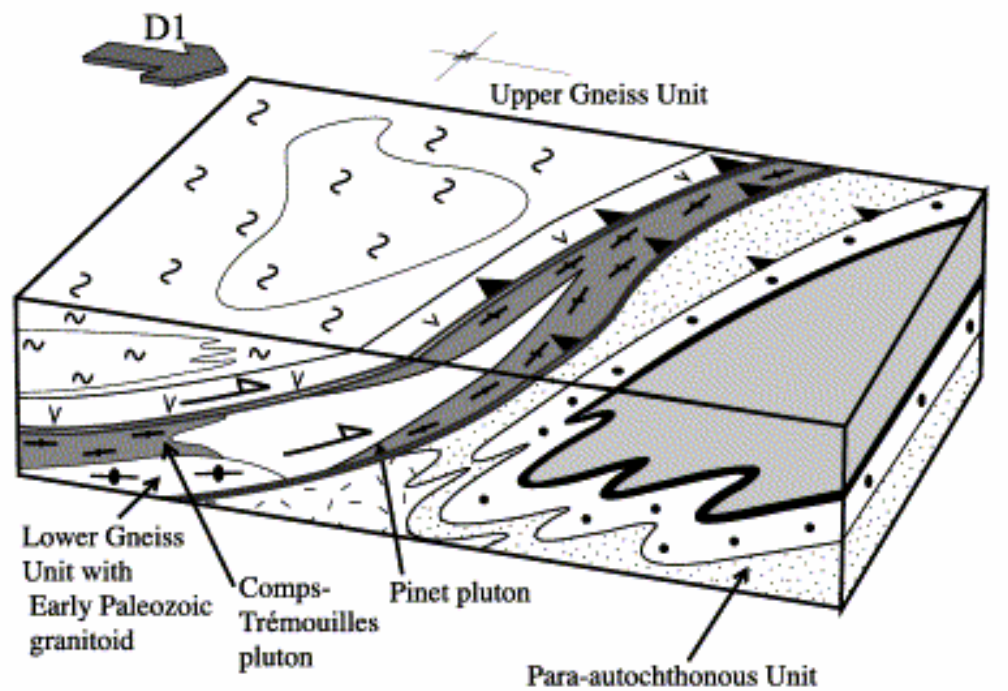

$360 \mathrm{Ma}: \mathrm{D} 2$ top-to-the NW transpressive event

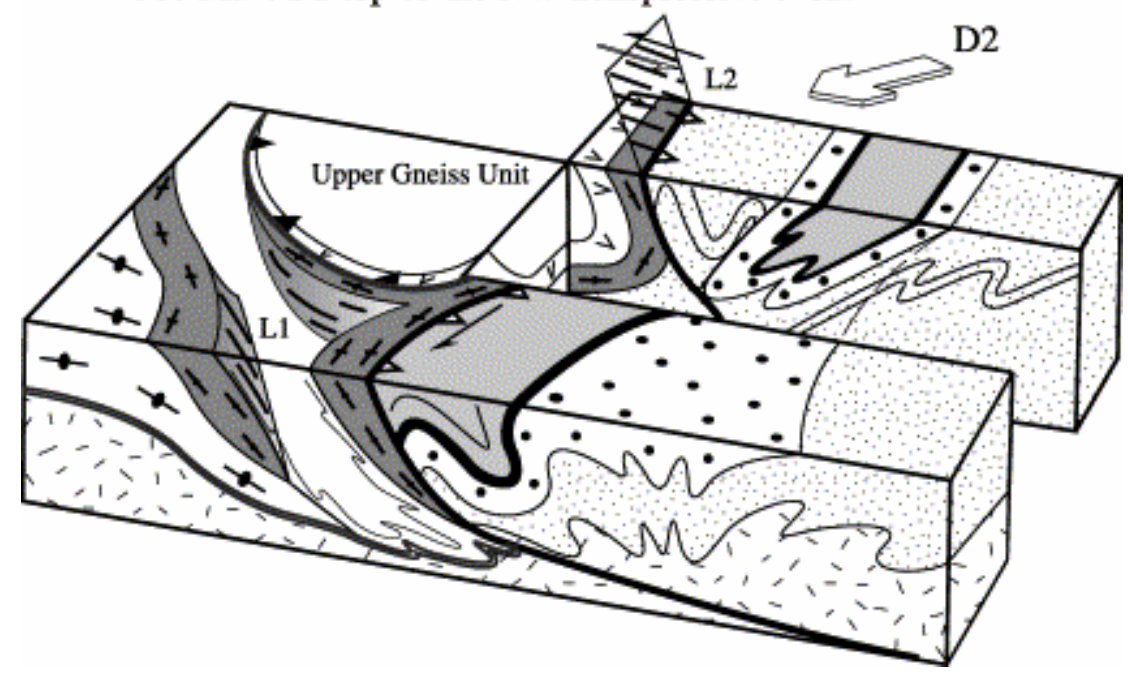

Fig. 11. Schematic block-diagram showing the structural evolution between the D1 top-to-the-SW thrusting and coeval Pinet and Comps-Trémouilles plutons emplacement, followed by the D2 top-to-the-NW transpressive event. The flat-lying S1 foliation is well preserved in the northern part of the study area. Further south the early D1 fabric is reworked by the dextral wrench-thrust of Pinet.

In the Rouergue area, the age of the D1 phase is still unknown. However, in the western part of the Massif Central, top-to-the-SW shearing equivalent to the D1 event is dated ca. 386-380 Ma (Duthou, 1977 and Lafon, 1986). A similar age would be also likely for the D1 event in the Rouergue area. The large uncertainty of the $\mathrm{U} / \mathrm{Pb}$ of zircon date $360 \pm 20 \mathrm{Ma}$ ( Pin, 1981) of the Pinet granite does not allow us to settle the age of the D1 event.

\section{Acknowledgements}

We acknowledge B.R.G.M. for financial support. Aaron Yoshinobu, Marcos Egydio-Silva and Keith Benn contributed greatly to improve the clarity and quality of our manuscript and 
are also acknowledged. The authors also wish to thank Dominique Panis who performed Xray texture goniometry analysis.

\section{References}

Bayer, R. and Hirn, A., 1987. Données géophysiques sur la structure profonde de la croûte hercynienne dans l'arc ibéro-armoricain et le Massif central Français. Bulletin de la Société Géologique de France 8, pp. 561-574.

Berthé, D., Choukroune, P. and Jegouzo, P., 1979. Orthogneiss, mylonite and non-coaxial deformation of granites: the example of the South Armorican Shear zone. Journal of Structural Geology 1, pp. 31-42.

Blumenfeld, P., Mainprice, D. and Bouchez, J.L., 1986. C-slip in quartz from subsolidus deformed granite. Tectonophysics 127, pp. 97-115.

Bouchez, J.L., 1977. Plastic deformation of quartzites at low temperature in an area of natural strain gradient. Tectonophysics 39, pp. 97-115.

Bouchez, J.L., Tubià, J.M. and Mainprice, D., 1985. Déformation naturelle du quartz: coexistence des systèmes de glissement de direction $\langle a\rangle$ et $\langle c\rangle$ à haute température (migmatites de la nappe d'Ojén, Espagne). Comptes Rendus de l'Académie des Sciences de Paris 301, pp. 841-846.

Burg, J.P. and Laurent, P., 1978. Strain analysis of a shear zone in a granodiorite. Tectonophysics 47, pp. 15-42.

Burg, J.P. and Teyssier, C., 1983. Contribution à l'étude tectonique et microtectonique des séries cristallophyliennes du Rouergue oriental: la déformation des laccolites syntectoniques, type Pinet. Géologie de la France 1, pp. 3-30.

Burg, J.P., Delor, C. and Leyreloup, A., 1986. Le massif du Lévézou et les séries adjacentes du Rouergue oriental. Nouvelles données pétrographiques et structurales. Géologie de la France 1, pp. 229-272.

Costa, S., 1992. East-West diachronism of the collisional age in French Massif central: implications for the European variscan orogen. Geodinamica Acta 5, pp. 51-68.

Delbos, L., Lasserre, M. and Roques, M., 1965. Géochronologie et rétromorphose dans la série cristallophyllienne du Rouergue (Massif Central français). Science de la Terre (Nancy) 10, pp. 329-342.

Duthou, J.L., 1977. Chronologie Rb-Sr et géochimie des granitoïdes d'un segment de la chaîne varisque. Relations avec le métamorphisme: le Nord-Limousin. Ph.D. thesis, Université de Clermont-Ferrand, Annales Scientifiques de l'Université de Clermont-Ferrand 63. 
Etchecopar, A. and Vasseur, G., 1987. A 3-D kinematic model of fabric development in polycrystalline aggregates: comparisons with experimental and natural examples. Journal of Structural Geology 9, pp. 705-717.

Faure, M., 1995. Late Carboniferous extension in the Variscan French Massif central. Tectonics 14, pp. 132-153.

Faure, M., Duguet, M., Cartier, C., Brunel, M., Gebelin, A., 2002. La tectonique éohercynienne d'âge tournaisienne vers le NW dans la Chaîne hercynienne française. 19ème Réunion des Sciences de la Terre, abstract no. 178, p. 117, Nantes, France.

Gapais, D., 1989. Shear structures within deformed granites: mechanical and thermal indicators. Geology 17, pp. 1144-1147. Abstract-GEOBASE

Gapais, D. and Barbarin, B., 1986. Quartz fabric transition in a cooling syntectonic granite (Hermitage Massif, France). Tectonophysics 125, pp. 357-370. Abstract

Garbutt, J.M. and Teyssier, C., 1991. Prism $\langle c\rangle$ slip in the quartzites of the Oakhurst Mylonite Belt, California. Journal of Structural Geology 13, pp. 657-666. Abstract

Gower, R.J.W. and Simpson, C., 1992. Phase boundary mobility in naturally deformed, highgrade quartzofeldspathic rocks: evidence for diffusional creep. Journal of Structural Geology 14, pp. 301-313. Abstract

Guérangé-Lozes, J. and Alsac, C., 1986. Les nappes varisques de l'Albigeois cristallin. Lithostratigraphie, volcanisme et déformations. Géologie de la France 3, pp. 309-337. Abstract-GEOBASE

Guérangé-Lozes, J. and Burg, J.P., 1990. Les nappes varisques du sud-ouest du Massif central (cartes géologiques et structurales à 1/250000 Montpellier et Aurillac). Géologie de la France 3-4, pp. 71-106. Abstract-GEOBASE

Hibbard, M.J., 1987. Deformation of incompletely crystallized magma systems: granitic gneisses and their tectonic implications. Journal of Geology 95, pp. 543-561.

Hippertt, J.F. and Hongn, F.D., 1998. Deformation mechanisms in the mylonite/ultramylonite transition. Journal of Structural Geology 20, pp. 1435-1448.

Hippertt, J.F., Rocha, A., Lana, C., Egydio-Silva, M. and Takeshita, T., 2001. Quartz plastic segregation and ribbon development in high-grade striped gneisses. Journal of Structural Geology 23, pp. 67-80.

Jessell, M.W., 1987. Grain-boundary migration microstructures in a naturally deformed quartzite. Journal of Structural Geology 9, pp. 1007-1014. Abstract

Jessell, M.W., Lister, G.S., 1990. A simulation of the temperature dependance of quartz fabrics. In: Knipe, R.J., Rutter, E.H. (Eds.), Deformation Mechanisms, Rheology and Tectonics. Geological Society Special Publication 54, pp. 353-362. 
Lafon, J.M., 1986. Géochronologie U-Pb appliquée à deux segments du Massif central français: le Rouergue oriental et le Limousin central. Ph.D. thesis, Université de Montpellier II.

Law, R.D., 1987. Heterogeneous deformation and quartz crystallographic fabric transitions: natural examples from the Moine Thrust zone at the Stack of Glencoul, northern Assynt. Journal of Structural Geology 9, pp. 819-833. Abstract

Law, R.D., 1990. Crystallographic fabrics: a selective review of their applications to research in structural geology. In: Knipe, R.J., Rutter, E.H. (Eds.), Deformation Mechanisms, Rheology and Tectonics. Geological Society Special Publication 54, pp. 335-352.

Ledru, P., Lardeaux, J.M., Santallier, D., Autran, A., Quenardel, J.M., Floc'h, J.P., Lerouge, G., Maillet, N., Marchand, J. and Ploquin, A., 1989. Où sont les nappes dans le Massif Central français?. Bulletin de la Société Géologique de France 8, pp. 605-618. AbstractGEOBASE

Lister, G.S. and Hobbs, B.E., 1980. The simulation of fabric development during plastic deformation and its application to quartzite: the influence of deformation history. Journal of Structural Geology 2, pp. 355-370. Abstract

Lister, G.S. and Snoke, A.W., 1984. S-C mylonites. Journal of Structural Geology 6, pp. 617-638. Abstract

Mainprice, D., Bouchez, J.L., Blumenfeld, P. and Tubià, J.M., 1986. Dominant c-slip in naturally deformed quartz: implications for dramatic plastic softening at high temperature. Geology 14, pp. 819-822.

Maluski, H. and Monié, P., 1988. ${ }^{39} \mathrm{Ar} /{ }^{40} \mathrm{Ar}$ laser probe multi-dating inside single biotites of a Variscan orthogneiss (Pinet, Massif central, France). Chemical Geology 73, pp. 245-263.

Mattauer, M., 1974. Existe t-il des chevauchements de type himalayen dans la chaîne hercynienne?. Colloques Internationaux du C.N.R.S. 268, pp. 261-267.

Matte, P., 1986. La chaîne varisque parmi les chaînes paléozoïques péri-atlantiques, modèle d'évolution et position des grands blocs continentaux au Permo-carbonifère. Bulletin de la Société Géologique de France 8, pp. 9-24.

Neumann, B., 2000. Texture development of recrystallised quartz polycrystals unravelled by orientation and misorientation characteristics. Journal of Structural Geology 22, pp. 16951711.

Paquette, J.L., Monchoux, P. and Couturier, M., 1995. Geochemical and isotopic study of a norite-eclogite transition in the European Variscan Belt: implications for $\mathrm{U}-\mathrm{Pb}$ zircon systematics in metabasic rocks. Geochimica et Cosmochimica Acta 59, pp. 1611-1622.

Passchier, C.W. and Trouw, R.A.J., 1998. Microtectonics, Springer, Berlin 298pp . 
Paterson, S.R., Vernon, R.H. and Tobisch, O.T., 1989. A review of criteria for the identification of magmatic and tectonic foliations in granitoids. Journal of Structural Geology 11, pp. 349-363.

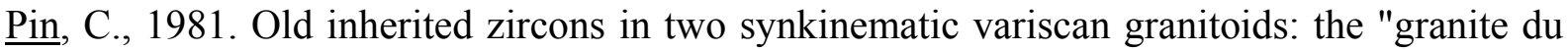
Pinet" and the "orthogneiss de Marvejols" (southern French Massif Central). Neues Jahrbuch für Mineralogie, Abhandlungen 142, pp. 27-48.

Pin, C. and Lancelot, J., 1982. U-Pb dating of an early Paleozoic bimodal magmatism in the French Massif Central and its further metamorphic evolution. Contribution to Mineralogy and Petrology 79, pp. 1-12.

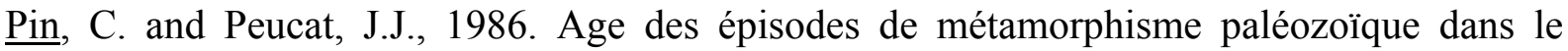
Massif Central et le Massif Armoricain. Bulletin de la Société Géologique de France 8, pp. 461-469.

Pons, J., Oudin, C. and Valero, J., 1992. Kinematics of large syn-orogenic intrusion: example of the Lower Proterozoic Saraya batholith (eastern Senegal). Geologische Rundschau 81, pp. $473-486$.

Roig, J.Y., Faure, M. and Ledru, P., 1996. Polyphase wrench tectonics in the southern French Massif Central. Kinematic inferences from pre- and syn-kinematic granitoids. Geologische Rundschau 85, pp. 138-153 